2013s-03

\title{
The Influence of Country- and Firm-Level Governance on Financial Reporting Quality: Revisiting the Evidence
}

\author{
Pietro Bonetti, Antonio Parbonetti, Michel Magnan
}

\begin{tabular}{c}
\hline Série Scientifique \\
Scientific Series
\end{tabular}

\author{
Montréal \\ Janvier 2013
}

(C) 2013 Pietro Bonetti, Antonio Parbonetti, Michel Magnan. Tous droits réservés. All rights reserved.

Reproduction partielle permise avec citation du document source, incluant la notice (C)

Short sections may be quoted without explicit permission, if full credit, including (C) notice, is given to the source.
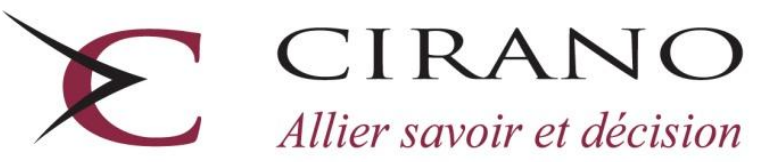

Allier savoir et décision

Centre interuniversitaire de recherche en analyse des organisations 


\section{CIRANO}

Le CIRANO est un organisme sans but lucratif constitué en vertu de la Loi des compagnies du Québec. Le financement de son infrastructure et de ses activités de recherche provient des cotisations de ses organisations-membres, d'une subvention d'infrastructure du Ministère du Développement économique et régional et de la Recherche, de même que des subventions et mandats obtenus par ses équipes de recherche.

CIRANO is a private non-profit organization incorporated under the Québec Companies Act. Its infrastructure and research activities are funded through fees paid by member organizations, an infrastructure grant from the Ministère du Développement économique et régional et de la Recherche, and grants and research mandates obtained by its research teams.

\section{Les partenaires du CIRANO}

\section{Partenaire majeur}

Ministère de l'Enseignement supérieur, de la Recherche, de la Science et de la Technologie

Partenaires corporatifs

Autorité des marchés financiers

Banque de développement du Canada

Banque du Canada

Banque Laurentienne du Canada

Banque Nationale du Canada

Banque Scotia

Bell Canada

BMO Groupe financier

Caisse de dépôt et placement du Québec

Fédération des caisses Desjardins du Québec

Financière Sun Life, Québec

Gaz Métro

Hydro-Québec

Industrie Canada

Investissements PSP

Ministère des Finances du Québec

Power Corporation du Canada

Rio Tinto Alcan

State Street Global Advisors

Transat A.T.

Ville de Montréal

\section{Partenaires universitaires}

École Polytechnique de Montréal

HEC Montréal

McGill University

Université Concordia

Université de Montréal

Université de Sherbrooke

Université du Québec

Université du Québec à Montréal

Université Laval

Le CIRANO collabore avec de nombreux centres et chaires de recherche universitaires dont on peut consulter la liste sur son site web.

Les cahiers de la série scientifique (CS) visent à rendre accessibles des résultats de recherche effectuée au CIRANO afin de susciter échanges et commentaires. Ces cahiers sont écrits dans le style des publications scientifiques. Les idées et les opinions émises sont sous l'unique responsabilité des auteurs et ne représentent pas nécessairement les positions du CIRANO ou de ses partenaires.

This paper presents research carried out at CIRANO and aims at encouraging discussion and comment. The observations and viewpoints expressed are the sole responsibility of the authors. They do not necessarily represent positions of CIRANO or its partners. 


\title{
The Influence of Country- and Firm-Level Governance on Financial Reporting Quality: Revisiting the Evidence
}

\author{
Pietro Bonetti ${ }^{*}$, Antonio Parbonetti ${ }^{\dagger}$, Michel Magnan ${ }^{*}$
}

\begin{abstract}
Résumé / Abstract
Depuis quelques années, le rôle et l'importance relative de la gouvernance au niveau organisationnel (entreprise) et de la gouvernance au niveau institutionnel (pays) sur plusieurs décisions et pratiques organisationnelles font l'objet d'un débat animé. Une des facettes de ce débat est l'impact des deux niveaux de gouvernance sur la crédibilité des résultats financiers présentés par les entreprises. La question est d'importance car elle sous-tend plusieurs interventions réglementaires en matière de gouvernance. Nous étudions cette problématique au moyen d'un échantillon comprenant un grand nombre d'entreprises européennes ayant adopté les normes comptables internationales (ou, International Financial Reporting Standards, IFRS), ce qui assure une certaine comparabilité des données. La gouvernance organisationnelle est représentée par différents attributs du conseil d'administration alors que la gouvernance institutionnelle est fonction du contexte d'intervention réglementaire et judiciaire dans un pays. La crédibilité des résultats financiers est présumée comporter trois dimensions: sont-ils informatifs, libres de manipulations comptables systématiques et non affectés par des décisions de gestion non justifiées? Trois résultats principaux se dégagent de nos analyses. Premièrement, l'adoption d'un nouveau référentiel comptable qui est présumé être plus rigoureux (IFRS) n'a pas d'incidence sur la crédibilité des résultats financiers. Deuxièmement, les entreprises de pays caractérisés par une gouvernance institutionnelle faible mais dotés d'un conseil d'administration solide voient la crédibilité de leurs résultats financiers s'améliorer suite à l'adoption obligatoire du référentiel IFRS. Par conséquent, pour les entreprises de ces pays, la gouvernance organisationnelle se substitue aux carences de la gouvernance institutionnelle. Finalement, on observe une amélioration de la crédibilité des résultats financiers rapportés par les entreprises dotées d'un conseil d'administration solide et en provenance de pays ayant une gouvernance institutionnelle rigoureuse, ce qui suggère que les deux niveaux de gouvernance sont complémentaires dans ce cas.
\end{abstract}

Using a large sample of European firms that mandatorily adopted IFRS, this paper assesses how firmlevel governance, as proxied by board attributes, and country-level enforcement interplay in affecting financial reporting quality. Financial reporting quality is assumed to have three dimensions: earnings informativeness, accruals management, and real earnings management. Three key findings emerge from our analyses. First, IFRS adoption per se does not seem to affect financial reporting quality. Second, in countries characterized by weak enforcement, strong board-level monitoring appears to enhance financial reporting quality, thus suggesting a substitutive effect between firm- and countrylevel governance. Third, in countries characterized by strong enforcement, firms with strong boardlevel monitoring exhibit a higher level of financial reporting quality than firms with weak board-level monitoring, thus suggesting that country-and firm-level governance are complementary. Overall, our findings help bridge the gap in the debate about the effects of country-and firm-level governance on the quality of financial reporting and provide further nuance on prior IFRS adoption research.

Keywords: IFRS; Corporate governance, Legal enforcement, financial reporting quality

Codes JEL : G14, G15, G18, G34, M41

\footnotetext{
* University of Padova.

${ }^{\dagger}$ University of Padova.

${ }^{\ddagger}$ John Molson School of Business, Concordia University.
} 


\section{INTRODUCTION}

This paper explores how country and firm-level governance mechanisms interplay and dovetail one another in influencing the quality of reported earnings. While there is extensive research on the mapping between a firm's governance mechanisms and its financial reporting quality as well as on the impact of countrylevel institutions and financial reporting quality, there is scant evidence as to how these two levels of governance jointly affect the quality of financial reporting.

In that regard, the adoption of International Financial Reporting Standards (IFRS) provides an interesting setting to assess the relative influence of each governance level. It is one of the most fundamental change in accounting regulation and, not surprisingly, has been examined extensively (see Barth 2006; Soderstrom and Sun 2010; Hail et al. 2010 for an overview). However, evidence regarding the economic benefits stemming from IFRS mandatory adoption is rather mixed. On one hand, it appears that the switch from local generally accepted accounting principles (GAAP) to IFRS leads to an increase in comparability, transparency, and financial reporting quality. On the other hand, it is still challenging to attribute such benefits to the IFRS adoption per se, with some evidence suggesting that most of the perceived benefits from IFRS adoption actually result from concurrent changes in the regulatory and enforcement environments. To the extent that the application of accounting standards provides insiders with substantial discretion, research stresses that firms' reporting behavior, and hence the observed financial reporting quality, is likely to be shaped by institutional factors and firm-level reporting incentives, rather than by a simple change in accounting standards (Ball et al. 2003; Leuz et al. 2003; Burgsthaler et al. 2006). Consistently, many previous studies (Daske et al. 2008; Christensen et al. 2012) suggest that there is a substantial heterogeneity in the effects of IFRS adoption due to the differences in the legal enforcement. This literature emphasizes the importance of the enforcement regime as the key driver of observed heterogeneity in financial reporting quality. In this vein, previous studies point toward an increase in financial reporting quality around the IFRS adoption only in countries with strong legal enforcement (Daske et al. 2008; Byard et al. 2011; Landsman et al. 2012), thus amplifying the divergence among countries: firms incorporated in countries with stricter enforcement rules benefit from IFRS adoption while all others do not. 
Those studies explain the heterogeneous effects of IFRS adoption across countries but data on financial reporting quality reveals that there is greater variability between firms that share similar legal environment characteristics than between firms that share a similar board structure (REFERENCE FOR THIS?). As a consequence, previous research fails to explain the heterogeneity within similar legal environment, thus leaving several relevant questions unanswered. For example, does financial reporting quality remain uniformly unchanged around IFRS adoption for all firms located in weak legal enforcement countries, and do firms in strong legal enforcement uniformly increase financial reporting quality? Moreover do firms located in weak enforcement countries sustain the costs of IFRS adoption without the benefits? In other words, is there any possibility for a firm located in a weak enforcement country to overcome the effect of legal enforcement and to benefit from IFRS adoption?

This paper tries to fill this gap in the literature by analyzing the joint effects of board-based monitoring mechanisms with country legal enforcement. To do so, using a difference in difference approach, we test whether board-based monitoring mechanisms substitute or complement legal enforcement in shaping the effects of IFRS on financial reporting quality. We operationalize financial reporting quality considering the informativeness of earnings (Landsman et al. 2012), accrual and real earnings management. Our sample consists of 4,425 firm-year observations from 14 European countries. Following Landsman et al. (2012), we measure earnings informativeness using abnormal return variability and abnormal trading volume. We measure accrualbased earnings management using the modified Jones model (Dechow et al. 1995). We estimate real earnings management considering the abnormal level of cash flow from operations, production costs and discretionary expenses (advertising, R\&D and SG\&A). In line with previous research, we combine the three measures of real earnings management into two aggregate metrics of real earnings management.

The most compelling challenge to our analysis is that the mandatory IFRS adoption occurs at the same time for all publicly listed companies in European countries. To ascertain that general trends or concurrent events unrelated to IFRS adoption do not drive the results, we employ a control sample of voluntary adopters that switch to IFRS at least three years before the mandatory adoption date (Byard et al. 2011). We perform four steps of analysis: 1) an examination of the average effect of the IFRS adoption per se; 2) an examination of the 
effect of the mandatory IFRS adoption considering the board-based monitoring mechanisms; 3) an examination of the effect of the mandatory IFRS adoption considering the country level of legal enforcement; and 4) an examination of the effect of the mandatory IFRS adoption considering both the country-level of legal enforcement and board-based monitoring mechanisms.

In the first analysis, using firm-year data from 2002 to 2008, we compare the change in earnings informativeness metrics, accrual and real-based earnings management in the treatment sample (mandatory IFRS adopters) to the change for the control sample (voluntary IFRS adopters) around the time of mandatory IFRS adoption. In this first test, we regress our proxies for financial reporting quality on indicator variables for the type of adopter (mandatory versus voluntary), the interaction between these indicator variables and indicator variables for the time period (pre- versus post-mandatory adoption), and a set of controls.

Next, still using a difference-in-difference approach, we test whether the effects of mandatory IFRS adoption on earnings informativeness, accrual and real-based earnings management show variation with respect to cross-sectional changes in the board monitoring level, as represented by various board attributes. To summarize the underlying latent construction of board monitoring, we create a standardized level of strict board monitoring level based on the principal component factor analysis of the board and directors characteristics. Specifically, the second test adds to the multivariate analysis described above the interactions of the firm measure of the strength of board monitoring level with the type of adopter (mandatory versus voluntary) and the time period (pre- versus post-mandatory adoption). In the third step, still using a difference-in-difference approach, we test whether the effects of mandatory IFRS adoption on accrual, real-based earnings management and earnings informativeness show variation with respect to cross-sectional changes in the strength of legal enforcement.

Finally, we investigate the joint effect of board-based monitoring level and the strength of legal enforcement on earnings informativeness, accrual, and real-based earnings management around the mandatory IFRS adoption. The idea is to analyze whether different board-monitoring levels interplay with the legal enforcement regimes in determining the effects of mandatory IFRS adoption. 
We find evidence that the mandatory switch to IFRS is not sufficient, per se, to change firms' reporting practices and, hence, has little if no impact on financial reporting quality. By contrast, we find that both country level and firm-level monitoring mechanisms have an effective role in shaping firms' reporting quality after a change in accounting standards. Indeed, we document an increase in financial reporting quality only for firms which have strong board-based monitoring mechanisms irrespective from the country of incorporation. Despite country-specific institutional characteristics, firm-level monitoring mechanisms, i.e. board composition, are a substantial determinant of financial reporting quality around IFRS mandatory adoption. Finally, when we employ both the country-level and firm-level partitioning variables, we find an increase in financial reporting quality for strong monitoring firms in weak legal enforcement countries and for weak monitoring firms in a strong legal environment. However, the latter effect is stronger for strong monitoring firms in the strong legal environment. Thereby, if firm-level monitoring mechanisms are a substitute for the legal system when it is weak, firm- and country-level monitoring mechanisms turn to be complements as the latter gets stronger.

Our paper contributes to the literature in two ways. First, to the best of our knowledge, this is the first paper that provides evidence of the role of board-based monitoring mechanisms into the consequences of mandatory IFRS adoption. Using the board monitoring level as partitioning variable, we capture firm-level heterogeneity in financial reporting quality around IFRS mandatory adoption. So far, research has explored the average impact of IFRS adoption or has focused on cross-country differences. Firm level heterogeneity is not so well explored. Only a few papers try to explore this point (Byard et al. 2011; Daske et al. 2012), but they focus only on firm level reporting incentives. Our results show that, despite the country of incorporation and after controlling for firm-specific reporting incentives, firms can take advantage from IFRS adoption to the extent they adopt strong board-based monitoring mechanisms. In doing so, we add to the literature on IFRS adoption that considers reporting quality stemming from the country-level legal institutional framework (Daske et al. 2008, Byard et al. 2010, Landsman et al. 2012).

Second, the paper contributes to the growing literature on the interplay between firm-level governance and country institutional characteristics. The findings point toward a substitution effects between firm-level monitoring mechanisms and country-level enforcement mechanisms when the legal system is lax, while board 
monitoring and legal enforcement complement each other when the legal system gets stricter. In a sense, our findings may help bridge the contrasting evidence provided by Durnev and Kim (2005) and Doidge et al. (2007) and suggest that complementarity or substitution in firm- and country-level governance is contextual.

The remainder of the paper is organized as follows. In section 2, we review the literature and develop the hypotheses. Section 3 presents the data and the research design. Section 4 and section 5 contains the main results and the additional analysis. Section 6 presents the robustness tests, while section 7 concludes.

\section{RELATED LITERATURE AND PREDICTIONS}

\section{Related literature}

Extant research documents substantial economic benefits around mandatory IFRS adoption.. Among other things, there are positive market reactions to events associated with mandatory IFRS adoption (Armstrong et al. 2010), an increase in financial reporting quality (Barth et al. 2008), an increase in market liquidity and a decline in the cost of capital (Daske et al. 2008, 2001, Li 2010), higher information content of earnings (Landsman et al. 2012), an increase in stock price informativeness (Beuselinck et al. 2009, DeFond et al. 2011a), an improvement in analyst information environment (Byard et al. 2011, Tan et al. 2011), and higher foreign investments (Bruggeman et al. 2009, Beneish et al 2010, DeFond et al. 2011b). While the evidences consistently points towards positive capital market effects associated with IFRS adoption, results on the impact of IFRS on financial reporting quality are mixed and rather controversial. Barth et al. (2008) find evidence of an increase in earnings quality while Ahmed et al (2012) suggest that because of the principle-based nature of IFRS and the lack of implementation guidance, earnings quality decreased after the mandatory adoption of IFRS. However, theoretically, accounting flexibility could be used to increase accounting numbers quality as well as to decrease financial reporting quality.

Moreover, it is challenging to attribute such effects to the IFRS adoption per se. To the extent that the application of accounting standards provides insiders with substantial discretion, research stresses that firms' reporting behavior, and hence the observed financial reporting quality, is likely to depend on countries' institutional frameworks, market pressures and firm-level characteristics rather than to a change in accounting standards (Ball et al. 2000, Leuz et al. 2003, Burgstahler et al. 2006, Wysocki 2011).. In this vein, Christensen et 
al. (2012) argue that the aforementioned benefits are not fully ascribable to IFRS mandatory reporting. Rather, to the extent that some European Union (EU) countries have started to make financial reporting enforcement mechanisms tighter around 2005, the documented capital-market benefits may be caused by both an IFRS effect or by a change in enforcement effect. Although it is a very difficult task to disentangle them, they find an increase in market liquidity around IFRS mandatory adoption only in five European countries that adopt stricter accounting enforcement mechanisms concurrent with IFRS mandatory adoption. This evidence suggests that care is needed in interpreting capital-market or financial reporting effects around IFRS mandatory adoption.

Moreover, all these studies agree that, by itself, a change in accounting standards, even toward a supposedly higher quality set, does not matter much for a change in firms' reporting practices. Wysocki (2011) underscores the importance of country-level factors and firms specific characteristics in shaping the effects of a change of accounting standards. Therefore, the application of a common set of accounting standards is unlikely to generate similar outcomes in term of financial reporting quality across different countries and firms. Consistently, extant literature documents heterogeneity in the effects around IFRS mandatory adoption driven by the strength or the change of a country legal enforcement, pointing out the crucial role of the rigorous implementation of a new set of rules.

So far, researches have focused only on the role of country-level institutions, while how and whether firmlevel characteristics and the interplay among country and firm characteristics shape financial reporting outcomes have been rarely analyzed. Daske et al. (2012) find that only firms that experience a substantial change in their reporting incentives are perceived to derive significant capital market benefits while other firms that switch to IFRS under a "tick-box" mentality do not experience capital market benefits. These results are interpreted as evidence that: (i) IFRS mandatory adoption per se has little effect on firms reporting practices; (ii) country-level infrastructures do not to account for all firm-level heterogeneity in financial reporting quality.

However, there is considerable evidence supporting the hypothesis that monitoring- oriented boards increase financial reporting quality by, for example, constraining earnings management (Dechow et al. 1996, Klein 2002, Peasnell 2005, Falaye 2012). Therefore the board of directors and its monitoring intensity could drive the change in financial reporting quality around IFRS mandatory adoption. However, although there is 
widespread consensus about the role of governance monitoring mechanisms on financial reporting quality, firmlevel corporate governance has received little attention ${ }^{1}$ in previous research on mandatory IFRS adoption.

This paper tries to fill this gap in the literature analyzing the role of corporate governance on financial reporting quality after the mandatory IFRS adoption.

\section{Predictions: Monitoring role of board of directors and IFRS adoption}

The idea underlying this paper is to exploit cross-sectional variations in board-based monitoring intensity to examine heterogeneity in financial reporting quality changes around IFRS mandatory adoption. So far, research shows substantial cross-sectional heterogeneity in the consequences of IFRS mandatory adoption. Evidence of changes of financial reporting quality is mixed and controversial with several studies pointing toward an increase in accounting quality (Barth et al. 2008; Barth et al. 2010; Gordon et al. 2009) while other papers suggest a decrease in accounting quality (Ahmed et al 2012; Atwood et al. 2011). Managers can use accounting flexibility either to convey critical information or to lower accounting quality. On the one hand, Barth et al. (2008) purports that IFRS can improve accounting quality because principles-based accounting standards are more difficult to be circumvented. On the other hand, their principles-based nature and the lack of implementation guidance provide significant flexibility that can be used to reduce accounting information quality.

In this context, governance monitoring mechanisms can play a pivotal role in shaping reporting quality. Firms under the scrutiny of sound boards and managers may use the inherent flexibility of accounting regulation to convey information of higher quality more than to increase information asymmetries (Lombardo and Pagano 2000). According to agency theory (Jensen and Meckling 1976), board independence, the independence of the audit committee and the financial expertise of independent audit committee members reduce managerial leeway thus increasing transparency and financial reporting quality. There is considerable evidence supporting the hypothesis that monitoring-oriented oriented boards constrain earnings management, thus increasing financial

\footnotetext{
${ }^{1}$ Verriest et al. (2012) is an exception. Verriest et al. (2012), focusing on a small sample of European firms, document a positive association between the strength of firm-level corporate governance and firms compliance with the first-time IFRS adoption requirements, providing early evidence on the crucial role played by firm-level monitoring mechanisms, at least in the degree of compliance at the firsttime IFRS adoption.
} 
reporting quality (Dechow et al. 1996, Klein 2002, Peasnell 2005, Falaye 2012). For example, Peasnell et al. (2005) show a negative effect of board independence on earnings management. In a consistent manner, Song et al. (2010) show that board independence reduces the concern over the reliability of fair value information.

More recently, there is evidence that points out how the degree of financial expertise of board members plays the major role in determining financial reporting quality, most likely by making the board of directors more effective in carrying out its monitoring duties (DeFond et al. 2005, Krishnan and Visvanathan 2008). De Fond et al (2005) show that markets react positively to the appointment of a financial expert on the audit committee. Moreover, Carcello et al. (2010) show the importance of accounting expertise on financial reporting quality, thus corroborating the idea that independence is not the only variable which affects accounting quality. Overall, prior research links firm-level corporate governance with financial reporting quality. Hence, we posit our first hypothesis:

H1: On average, firms with strong board-based monitoring enjoy a larger increase in financial reporting quality around IFRS mandatory adoption than firms with weak board-based monitoring.

According to the new institutional accounting theory (Wysocki 2011), the outcomes of a change in accounting standards are shaped both by country-level institutions and firm-level characteristics, like the structure of board of directors, ownership structure or auditor quality. According to Wysocki (2011), financial reporting outcomes are likely to depend both on macro-institutions (e.g., capital markets' regulation, corporate law prescriptions and the legal enforcement) and micro-institutions (e.g., corporate governance). So far, the literature highlights the importance of countries' legal frameworks for reporting incentives by comparing between-countries cross-sectional differences in the consequences of IFRS adoption with respect to a given outcome variable while governance has not been examined.

However, how firm-level corporate governance and country-level legal institutions interact is still controversial. On the one hand, in countries where investors rights are stronger and better enforced, capital markets are more developed, firms practice better governance and are valued higher than in less investor friendly 
countries (La Porta et al. 1997, 1998) . A country institutional system frames firm-level corporate governance attributes that a firm decides to adopt (Doidge et al. 2007), through its effect on the cost of implementing governance practices. In contrast, in weak investor protection countries, it could be overly expensive for a firm to adopt strong corporate governance mechanisms, as the pay-off could be negligible. In stronger investor protection countries, firms may expect more benefits from adopting strong governance mechanisms as effective legal infrastructures make it economically feasible to bond to good governance. As a consequence, we may expect that governance and the strength of legal enforcement complement each other in countries with strong regulatory oversight while there are negligible effects in weak enforcement countries.

On the other hand, stronger and well-disciplined corporate governance mechanisms should be more valuable and important in mitigating the negative effects of an ineffective legal system where the regulation is lax and investor rights are weak and badly enforced (Durnev and Kim 2005, Chen et al. 2009). In such countries, indeed, investors cannot rely on the legal system to monitor insiders' behaviors. In this vein, we may expect that governance complements the legal system where the legal system is strong and substitute country-level enforcement where it is lax.

However, the literature on the relation between country-level legal/institutional factors and firm-level corporate governance mechanisms is still tentative and provides mixed evidence. Hence, it remains an empirical questions as to how firm-level monitoring mechanism and country level institutional factors jointly shape the consequences of IFRS mandatory adoption on financial reporting quality. Our second hypothesis, stated in the null form, is:

H2: The the strength of country-level legal enforcement does not moderate the effect of board-based monitoring mechanisms on financial reporting quality after IFRS mandatory adoption..

\section{DATA AND RESEARCH DESIGN}

\section{Sample Selection}


We obtain accounting and market data from Compustat Global, and analyst forecast data from the I/B/E/S international (split unadjusted) database. We identify from Compustat all public companies domiciled in Europe from 2002 to 2008. We eliminate firms in banking and financial industry (SIC codes between 6000-6500) and require at least eight observations in each two-digit SIC grouping per year and country to estimate accrual-based and real earnings management metrics. We combine accounting and market data with the analyst forecast data from $\mathrm{I} / \mathrm{B} / \mathrm{E} / \mathrm{S}$. To be included in the sample, we require each firm to have data available for at least one period before and one period after the mandatory adoption deadline (i.e. fiscal years beginning on or after the January 1, 2005). Finally, we require that each firm-year observation have data necessary to calculate the variables used in the analysis.

Next, we identify mandatory IFRS adopters by retrieving information on a firm's accounting standards followed from Compustat Global. We define mandatory adopters those firms that do not adopt IFRS until it becomes mandatory $^{2}$ (i.e. fiscal-years beginning on or after 01/01/2005). To account for concurrent events, we identify a control sample of European firms that voluntary adopted IFRS at least three years before the mandatory adoption date. These restrictions yield a final sample of 4,425 firm-year observations from 14 European countries from 2002 to 2008.

Finally, for each firm-year, we manually identify the composition of the board from the annual reports, and extract information about each director role, independence status, service on board audit committee, and work experiences. Information about directors' primary occupation in these filings is often missing or incomplete. Hence, we collect additional information from other sources (i.e. BoardEx, Thomson One, LexisNexis). Finally, data on the ownership structure comes from Amadeus - Bureau van Dyck database. Table 1 illustrates the sample distribution by country. The number of observations varies widely across countries: Austria has the lowest number of observations (9), and the UK has the highest $(1,619)$. In the last column, we report the values of the legal enforcement variable (Kaufman et al. 2007), which documents a substantial variation in the legal enforcement across the sample countries: Italy has the lowest value (0.5), and Switzerland has the largest (2.00).

\footnotetext{
${ }^{2}$ A firm is classified as mandatory IFRS adopters if the data item "astd" in Compustat global does not equal "DI" prior to fiscal year beginning on or after January 1, 2005. If a firm adopts IFRS after 2005, we drop it from the sample.
} 


\section{[INSERT TABLE 1 ABOUT HERE]}

\section{Financial Reporting Quality Metrics}

Following Landsman et al. (2012), we capture market-based financial reporting quality using the information content of earnings announcements operationalized with abnormal stock return volatility and abnormal trading volume. We compute abnormal stock return volatility at the earnings announcement dates as the ratio between the event window return volatility and the non-event window return volatility. To estimate the market model, we employ a non-event window of $t-60$ to $t-10$ and $t+10$ to $t+60$, while the event window runs from $t-1$ to $t+1$, where $t$ is the earnings announcement date.

$R_{i t}=\alpha_{i}+\beta_{i} R_{m t}+\varepsilon_{i t}$

Where $\mathrm{R}_{\mathrm{it}}$ is the stock return of firm $i$ for day $t$, and $\mathrm{R}_{\mathrm{mt}}$ is the equal-weighted return for all within country firms in the sample for day $t$ (DeFond et al., 2007), and $\alpha_{i}$ and $\beta_{\mathrm{t}}$ are firm $i$ 's market model estimates, each of which is calculated during $t$ non-event period. Estimates of the coefficients of the market model are used to estimate daily abnormal returns using the equation:

$$
A R_{i t}=R_{i t}-\left(\hat{\alpha}_{i}+\hat{\beta}_{i} R_{m t}\right)
$$

Abnormal stock return volatility (AVAR) is the ratio between the mean of the squared market model abnormal returns $\left(\mathrm{E}\left[\mathrm{AR}^{2} \mathrm{it}\right]\right)$, and the variance of a firm's $i$ market model residuals during the non-event window $\left(\sigma_{i}^{2}\right)$. To reduce the skewness, we take the natural logarithm (i.e. AVAR $\left.=\log \left(E\left[u^{2}{ }_{i t}\right] / \sigma_{i}^{2}\right)\right)$.

We measure the abnormal trading volume (AVOL) as the ratio between the mean of the event window volume $\left(\mathrm{V}_{\mathrm{it}}\right)$ and the mean of the non-event window trading volume $\left(\mathrm{E}\left[\mathrm{V}_{\mathrm{i}}\right]\right)$. Daily volume around earnings 
announcement date, $\mathrm{V}_{\text {it }}$, is shares of firm $i$ traded during day $t$ divided by share outstanding of firm $i$ at day $t-1, t$ $=0$ and $t+1$, where $t$ is the earnings announcement day; $\mathrm{V}_{\mathrm{i}}$ is the average daily trading volume for firm $i$ for days $t-60$ to $t-10$ and $t+10$ to $t+60$ relative to the $\mathrm{I} / \mathrm{B} / \mathrm{E} / \mathrm{S}$ earnings announcement date. As for AVAR, this ratio is highly skewed, hence our measure of abnormal trading volume is the natural logarithm of this ratio (i.e., AVAL $\left.=\log \left(E\left[V_{i t}\right] / E\left[V_{i}\right]\right)\right)$. For both AVAR and AVOL, higher values represent a higher information content of earnings announcements and hence a higher financial reporting quality.

We use a cross-sectional model of discretionary accruals, where for each year and country we estimate the model for every industry classified by its two-digit SIC code. In this way, we partially control for industry changes in economic conditions that affect total accrual while allowing the coefficient to vary across groups (DeFond and Jiambalvo 1994). We estimate the modified cross-sectional Jones model (Jones 1991) as described in Dechow et al. (1995):

$\frac{T A_{i j t}}{\text { Assets }_{i j t-1}}=\beta_{1} \frac{1}{\text { Assets }_{i j t-1}}+\beta_{2} \frac{\Delta R E V_{i j t}}{\text { Assets }_{i j t-1}}+\beta_{3} \frac{P P E_{i j t}}{\text { Assets }_{i j t-1}}+\varepsilon_{i j t}$

Where $\mathrm{TA}_{\mathrm{ijt}}$ is a firm's $i$ total accruals in year $t$ and two-digit sic code $j$, measured as net income before extraordinary items and discontinued operations minus operating cash flow; Assets $\mathrm{ijt}_{\mathrm{jt}}$ is a firm's $i$ total assets in year $t-1$ and two-digit sic code $j ; \Delta \mathrm{REV}_{\mathrm{ijt}}$ is the change in revenues from the preceding year for firm $i$ in twodigit sic code $j$; $\mathrm{PPE}_{\mathrm{ijt}}$ is the gross property plan and equipment for firm $i$ in two-digit sic code $j$ in year $t .^{3}$ The coefficient estimates from equation (1) are used to estimate firm-specific normal accruals (NA) for the sample firms:

$N A_{i j t}=\hat{\beta}_{1} \frac{1}{\operatorname{Assets}_{i j t-1}}+\hat{\beta}_{2} \frac{\Delta R E V_{i j t}-\Delta A R_{i j t}}{\operatorname{Assets}_{i j t-1}}+\hat{\beta}_{3} \frac{P P E_{i j t}}{\operatorname{Assets}_{i j t-1}}$

\footnotetext{
${ }^{3}$ To mitigate the undue influence of outliers, we winsorize all variables entering in the modified Jones model at the 1st and 99th percentiles.
} 
where $\Delta \mathrm{AR}_{\mathrm{ijt}}$ is the change in account receivable from the preceding year for firm $i$ in two-digit sic code $j$. Our measure of discretionary accruals is the difference between total accruals and the predicted normal accruals from equation (2), defined as $\mathrm{DA}_{\mathrm{ijt}}=\left(\mathrm{TA} /\right.$ Asset $\left._{\mathrm{ijt}-1}\right)-\mathrm{NA}_{\mathrm{ijt}}$. To the extent that we do not predict any given direction for accrual-based earnings management, we compute the absolute value of discretionary accruals and refer to it as ABS_DA.

Following Roychowdhury (2006), we use the abnormal level of cash flow from operation (R_FCFO), the abnormal level of production costs (R_PROD) and the abnormal level of discretionary expenses to capture the manipulation of real activities (R_DISC). We model the normal level of cash flow from operations as a linear function of sales and change in sales. Consistent with prior works, we estimate the following model for each country-year and industry defined by its two-digit SIC code.

$\frac{\text { CFO }_{i j t}}{\text { Assets }_{i j t-1}}=\beta_{1} \frac{1}{\operatorname{Assets}_{i j t-1}}+\beta_{2} \frac{\operatorname{SALES}_{i j t}}{\operatorname{Assets}_{i j t-1}}+\beta_{3} \frac{\Delta \operatorname{SALES}_{i j t-1}}{\operatorname{Assets}_{i j t-1}}+\varepsilon_{i j t}$

Where $\mathrm{CFO}_{\mathrm{ijt}}$ is cash flow from operations for firm's $i$ in year $t$ and two-digit sic code $j$; SALES $\mathrm{ijt}_{\mathrm{ijt}}$ is the net sales for firm's $i$ in year $t$ and two-digit sic code $j ; \Delta$ SALES $_{\mathrm{ijt}}$ is the change in net sales from the preceding year for firm $i$ in two-digit sic code $j$. Firms that engage in real earnings management have a lower level of abnormal cash flow than do other firms. Hence, we multiple the abnormal level of cash flow by minus one, so that higher values represent higher value of manipulation.

To estimate the normal level of production cost, first we model normal cost of goods sold (COGS) and inventory growth $(\triangle \mathrm{INV})$ using the following linear functions:

$$
\begin{aligned}
& \frac{\operatorname{COGS}_{i j t}}{\operatorname{Assets}_{i j t-1}}=\beta_{1} \frac{1}{\operatorname{Assets}_{i j t-1}}+\beta_{2} \frac{\operatorname{SALES}_{i j t}}{\operatorname{Assets}_{i j t-1}}+\varepsilon_{i j t} \\
& \frac{\Delta I N V_{i j t}}{\operatorname{Assets}_{i j t-1}}=\beta_{1} \frac{1}{\operatorname{Assets}_{i j t-1}}+\beta_{2} \frac{\Delta \operatorname{SALES}_{i j t}}{\operatorname{Assets}_{i j t-1}}+\beta_{3} \frac{\Delta \operatorname{SALES}_{i j t-1}}{\operatorname{Assets}_{i j t-1}}+\varepsilon_{i j t}
\end{aligned}
$$


Using equations (3) and (4), we estimate the normal level of production cost for each country, year, and industry as follows:

$$
\frac{\operatorname{PROD}_{i j t}}{\operatorname{Assets}_{i j t-1}}=\beta_{1} \frac{1}{\operatorname{Assets}_{i j t-1}}+\beta_{2} \frac{\operatorname{SALES}_{i j t}}{\operatorname{Assets}_{i j t-1}}+\beta_{3} \frac{\Delta S A L E S_{i j t}}{\operatorname{Assets}_{i j t-1}}+\beta_{4} \frac{\Delta S A L E S_{i j t-1}}{\operatorname{Assets}_{i j t-1}}+\varepsilon_{i j t}
$$

Where PROD ${ }_{\mathrm{ijt}}$ is defined as the sum of the cost of goods sold (COGS ${ }_{\mathrm{ijt}}$ ) and the change in inventory $\left(\triangle \mathrm{INV}_{\mathrm{ijt}}\right)$ for firm's $i$ in year $t$ and two-digit sic code $j$; SALES ${ }_{\mathrm{ijt}}$ is the net sales for firm's $i$ in year $t$ and twodigit sic code $j ; \Delta$ SALES $_{\mathrm{ijt}}$ is the change in net sales from the preceding year for firm $i$ in two-digit sic code $j$; The abnormal level of production costs (R_PROD) is defined as the residuals from equation (5). The higher the residuals, the higher the inventory overproduction, and the larger is the increase in the earnings by reducing the cost of goods sold.

The normal level of discretionary expenses is modeled as

$$
\frac{\operatorname{DISCX}_{i j t}}{\operatorname{Assets}_{i j t-1}}=\beta_{1} \frac{1}{\operatorname{Assets}_{i j t-1}}+\beta_{2} \frac{\operatorname{SALES}_{i j t-1}}{\operatorname{Assets}_{i j t-1}}+\varepsilon_{i j t}
$$

Where DISCX ${ }_{\mathrm{ijt}}$ is a firm's $i$ discretionary in year $t$ and two-digit sic code $j$, and it is computed as the sum of advertising expenses, R\&D expenses, and Selling, General and Administrative expenses. Abnormal discretionary expenditures (R_DISC) is defined as the residuals from equation (6). We multiply the residuals by minus one, such that higher values indicate greater amounts of discretionary expenditures cutting to inflate earnings upward. Finally, we aggregate the three real earning management proxies into two aggregate measures by taking their sum. We compute REAL_1 as the sum between abnormal production cost and abnormal discretionary expenses, and REAL_2 as the sum between abnormal discretionary expenses and abnormal cash flow from operations. Higher values of both these proxies suggest a higher level of real earnings management.

\section{Corporate Governance Score}


We capture the strength of board-based monitoring mechanisms for each sample firm by combing six governance attributes into a binary variable through a factor analysis (Larcker et al. 2007, Song et al. 2010). To the extent that strong governance on manifold facets reveals a stronger governance environment, our proxy should better summarize the overall strength of a firm governance mechanisms than a unique measure (Bushman et al. 2004, DeFond et al. 2005). The six governance attributes include (1) board independence (INDEPENDENT), as the number of independent directors divided by board size; (2) a dummy variable (AUDIT) for the presence of an audit committee; (3) audit committee size (AUDIT_SIZE); (4) audit committee independence (INDEPENDENT_AUDIT), as the number of independent board members serving on the audit committee over audit committee size; (5) audit committee financial expertise (FINANCIAL_EXPERT_AUDIT), as the number of audit committee members with financial expertise divided by the size of the audit committee; (6) total percent shares held by institutional investors (INST_OWN). ${ }^{4}$ Such measures depict several attributes of a firm corporate governance strength that we employ to measure board-based monitoring intensity.

Independent directors are believed to be willing to stand up to the insiders and more effective than non-independent directors in mitigating agency problems between insiders and outside investors (Fama 1980). The audit committee's main duty is to oversee the financial reporting process to guarantee the integrity and the credibility of financial reports. We first consider: (1) the presence of an audit committee (Peasnell et al. 2005), (2) the audit committee size (DeFond et al. 2005), (3) its degree of independence (Klein 2002). Next, we consider the financial expertise of its members (DeFond et al. 2005). As recognized by the US Congress and the SEC, financial expertise is a necessary condition to ensure that the audit committee fulfils its monitoring duties (SEC [2003b], US Senate 2002, 32). To construct this variable, we follow the DeFond et al. (2005) and the SOX Section 407 definition of financial expertise in both the first version proposed and in the last implemented by the SEC (SEC 2002, SEC 2003b, SEC 2003c). We read each board member biographical sketch to classify each independent director into one of the following categories: (1) SOX financial experts as all directors who have financial expertise as defined in the last version of SOX; (2) Nonfinancial expert as all directors who do not meet

\footnotetext{
${ }^{4}$ We do not include board size as a determinant of the governance factor score for several reasons. Literature provides mixed evidence on the effect of board size on monitoring effectiveness. In addition, board size is highly correlated with firm size and, in a cross-country sample it is subjected to the different national legislations. However, we do compute the factor score also including board size. The results remain unchanged.
} 
the definition of a SOX financial expert. Even if this coding requires some judgment, we strictly follow the guidelines provided in the proposed and final SEC rules. Basically, we label a director as a financial expert if she has experiences as public accountant, auditor, $\mathrm{CFO}$, controller, chief accounting officer (these are inferred from the proposed rules by the SEC) or has experience as CEO of executives of a for-profit organization (these are drawn from the final version of SOX implemented by the SEC). Audit committee members with financial expertise should be more familiar with the ways that earnings can be managed. On the contrary, an audit committee without financial expert members may be largely ceremonial. Finally, we consider the percentage of shares held by institutional investors as they improve a firm corporate governance environment by constraining insiders’ behaviour (Nesbitt 1994).

Table 2, panel A provides descriptive statistics for governance attributes. Next, we apply a principal component factor analysis to the six governance attributes (Larcker et al. 2007, Song et al. 2010). The first and primary factor exhibits the expected loadings (Table 3, panel B). The factor analysis generates an eigenvalue of $3.4639^{5}$, which accounts for about $57.73 \%$ of the total variance in the original variables. Table 2 , panel B, second column reports the Kaiser-Meyer-Olkin measure of sampling adequacy. Each variable is associated with a value greater than 0.6 , and the mean KMO value is about 0.7533 , indicating that the GOVSCORE is able to capture well the underlying common factor of the six individual variables. Panel $\mathrm{C}$ reports the descriptive statistics for GOVSCORE. Due to the standardization, such a variable has mean 0 and standard deviation of 1 . Next, we take the firm-specific mean of GOOVCORE across the sample years. Finally, we create a binary variable (GOOD_GOV) based on the sample median of the firm-specific mean of GOOVCORE ${ }^{6}$. Specifically, we classify firms with above sample median value of the firm-specific mean of GOVSCORE as strong board-based monitoring firms (GOOD_GOV equals to one).

\footnotetext{
${ }^{5}$ The second factor is associated with an eigenvalue of 0.9372 . For this reason it is not retained.

${ }^{6}$ In this way we do not assume that board monitoring intensity does not vary over time. Instead,we assume that the cross-sectional difference in board monitoring intensity across firms does not. We relax this assumption later and obtain similar results. Note, however, that less than $6 \%$ of the firms in our sample went from being classified as weak (strong) board-based monitoring firms in the pre mandatory adoption period to being classified as strong (weak) board-based monitoring firms in the post mandatory adoption period. Overall, board composition and thus monitoring intensity seems to be quite stable over time.
} 
[INSERT TABLE 2 ABOUT HERE]

\section{Empirical Models}

We investigate the impact of firm-level board monitoring intensity and the interactive effect of firm-level board monitoring intensity and country-level legal enforcement on financial reporting quality around IFRS mandatory adoption employing a difference-in-difference design. This approach is commonly used in the IFRS literature (Li 2010, Byard et al. 2011, Landsman et al. 2012) to analyze the change in a given metric of interest in the pre- versus post-mandatory adoption period for mandatory adopters relative to the change for a control sample of firms over the same time period. Using a control sample of voluntary adopters allows us to take into account the effects of potentially confounding events around IFRS mandatory adoption. Secondly, the difference-in-difference design alleviates concerns about unobserved heterogeneity across firms or timeinvariant selection bias. This issue may be particularly severe in corporate governance research, to the extent that board composition is endogenous. In our setting, there may be many reasons for board composition and financial reporting quality to be jointly determined by some unobserved firm characteristics. If these unobserved firm characteristics are time invariant, then a difference-in-difference design which exploits IFRS mandatory adoption as an exogenous event addresses simultaneous determination problems.

We begin our first set of analyses with a parsimonious model which regresses financial reporting quality metrics on indicators variable for the type of adopters (mandatory versus voluntary adopters), the interaction between them and indicators variable for the time $\operatorname{period}^{7}$ (pre- versus post-mandatory adoption period), and a set of control variables. Consistent with prior research, by such analysis we intend to verify to what extent, on average, IFRS mandatory adoption is associated with an increases in financial reporting quality:

$$
\begin{aligned}
\mathrm{Y} & =\beta_{1}{ }^{*} \mathrm{M} \text { ANDATORY } \beta_{2} * \text { VOLUNTARY }+\beta_{3} * \text { M ANDATOR POST } \\
& +\beta_{4} * \text { VOLUNT ARYPOST }+\sum \beta_{\mathrm{J}} * \text { CONTROLS } \varepsilon_{\mathrm{it}}
\end{aligned}
$$

\footnotetext{
${ }^{7}$ For ease of exposition, we do not include the intercept in the models, but indicator variables for both the groups. As a result, we include POST only interacted with MANDATORY and VOLUNTARY.
} 
where Y stands for the abnormal return variability, abnormal trading volume, and the earnings management metrics (accrual-based and real earnings management). CONTROLS denotes the set of control variables that differ according to the particular dependent variable used. The variables of interest are MANDATORY, which takes the value of one when a firm does not apply IFRS until it becomes mandatory in 2005, and 0 otherwise; VOLUNTARY which takes the value of one if a firm applies IFRS before 2002, and 0 otherwise. The third (fourth) variable of interest is the interaction between MANDATORY (VOLUNTARY) and POST, which is an indicator variable which takes the value of one if an observation relates to the mandatory post adoption period. The interaction between MANDATORY and POST measures the difference in change in the financial reporting quality metrics between the pre- versus post-mandatory adoption period for mandatory adopters.

Next, we exploit cross-sectional variation in the level of board-based monitoring to examine the marginal effect of firm-specific monitoring intensity on financial reporting quality around IFRS mandatory adoption. Different from extant literature that has explored the role of country institutional variables, we emphasize the role of firm-level governance mechanisms as drivers of the change in financial reporting quality around IFRS mandatory adoption. We predict an increase in financial reporting quality only for firms with strong board-based monitoring mechanisms, regardless of the country of incorporation. We proxy for the intensity of the boardlevel monitoring intensity using GOOD_GOV, as previously defined. We thus augment model (11) to include the interaction between adopter type, POST, and the proxy for board-level monitoring intensity (GOOD_GOV) [model (12)].

Finally, we explore the interplay between country-level institutional characteristics and firm-level boardbased monitoring intensity. On the one hand, a better institutional framework should reduce the costs a firm incurs in adopting good governance and positively shape the benefits of doing so. On the other hand, good corporate governance should be more important and valuable in alleviating the negative effects of a lax legal environment when the enforcement is weak, as long investors cannot rely on the legal system alone (Durnev et al. 2005, Chen et al. 2009) to protect themselves. As a result, it is an empirical questions as to whether the extent to which country-level legal enforcement and firm-level corporate governance are complements or substitutes in 
determining financial reporting quality. We proxy for the strength of a country legal enforcement using the "Rule of Law" variable for 2005 (Kaufmann et al., 2007, Daske et al. 2008). We next transform this measure into a binary variable (HIGH_LAW) as we split observations based on the median of the sample. Then, still using a difference-in-difference design, we augment model (11) to include the full interaction between adopter type, POST, GOOD_GOV and HIGH_LAW [(model (13)].

\section{Control Variables}

All the models include year-country-industry [using the Campbell (1996) industry classification] fixed effects $^{8}$ and heteroskedasticity-corrected standard errors, adjusted at firm-level clustering (Gow et al. 2010). According to the financial reporting quality metrics used, we include a set of controls variables. In the accrualbased and real earnings management regressions, we control for several factors that are associated with financial reporting quality. We control for firm size (SIZE) using the log of a firm total asset to control for the effect of firms' size on financial reporting quality. We include growth prospects, as the percentage change in sales (GROWTH) as there is evidence that it influences earnings management (Barth et al. 2008). LEV, as the end-ofyear total liabilities divided by the end-of-year book value of equity, and DISSUE, as the percentage change in total liabilities, take into account debt-contracting motivations for earnings management (DeFond and Jiambalvo 1994). We control for performance using return on assets (ROA), as net income over the end of the year total assets, and TURN as sales divided by end of the year total assets. Firms that meet/beat analyst forecasts could have managed earnings upward to make analyst expectations, therefore we include a binary variable equals to one if a firm meet/beat analyst forecasts, zero otherwise (MBE). We control for innate factors relating to the firm's operating environment that are likely to be associated with financial reporting quality (Hribar and Nichols 2007). We include: the variability in operating cash flows $[\sigma(\mathrm{FCFO})]$, variability in sales $[\sigma(\mathrm{SALES})]$, both measured as a rolling standards deviation over the past five years, and the length of the operating cycle (OPER_CYCLE). Finally, we account for macroeconomic factors using the log of the annual change in the ratio of stock market capitalization and gross domestic product per capita (CAP/GDP), taken from the World Bank.

\footnotetext{
${ }^{8}$ To avoid multi-collinearity problems, we do not include country dummies when we partition the sample according to the strength of the legal enforcement.
} 
This variable is used in international research (Haw et al. 2004) to deal with unobserved country-specific factors that may be associated with financial reporting quality.

In the AVAR and AVOL regressions, we control for SIZE, LEV, LOSS and $\triangle \mathrm{CAP} / \mathrm{GDP}$. We include ESTIMATE, as the log of the number of analyst forecasts made during the year, that account for the strength of the monitoring carried out by analysts (Das et al. 2011). We include also: DISPERSION, as the standard deviation of analyst forecasts prior to the earnings announcement, scaled by the closing price as the end of the year; AFE, as the difference between the actual earnings per share and the analyst consensus earnings forecast before the earnings announcement, scaled by the closing price at the fiscal year end, that capture the uncertainty in the analyst information environment; and REP_LAG is logarithm of the number of days between the firm's fiscal year end to the earnings announcement.

\section{RESULTS}

Table 3 presents descriptive statistics for the variables used in the regression analyses. The mean (median) value of AVAR is $0.17(0.19)$, while the mean (median) value of AVOL is $0.62(0.51)$. The mean (median) value of the absolute discretionary accruals is 0.056 (0.039), while the average values for the aggregate real earnings management variables are -0.046 (-0.029) for REAL 1 and -0.043(-0.030) for REAL 2.

\section{[INSERT TABLE 3 ABOUT HERE]}

We start our empirical analyses by exploring the average change in financial reporting quality, operationalized as the information content of annual earnings announcements, around IFRS mandatory adoption. We employ a difference-in-difference design to compare the change in financial reporting quality for mandatory adopters relative to the change for a control sample of voluntary adopters. Estimating the average effect allow us a comparison with prior work. Table 4, panel A, models (1)-(2) reports the results when we use AVAR and AVOL as dependent variables. The coefficient of the interaction between POST and MANDATORY is insignificant in model (1) which employs AVAR as dependent variable, while it is positive and significant in 
model (2), where AVOL is the dependent variable. The control variables behave as expected. Collectively, these results suggest that the mandatory switch to IFRS is not sufficient, per se, to change firms' reporting practices and, hence, it has a little impact on financial reporting quality.

Next, still employing a difference-in-difference deign, we test to what extent the effects of IFRS mandatory adoption on financial reporting quality are determined by country-level and firm-level monitoring mechanisms. To benchmark our findings with prior studies, we first use as partitioning variable the country-level proxy for the enforcement intensity (i.e. HIGH_LAW). If IFRS mandatory adoption has different effects across countries in function of the legal enforcement, we should observe an increase in the information content of annual earnings announcements only in strong legal enforcement countries. Table 4, models (3)-(4) reports the coefficients and firm-level clustered adjusted t-statistics from the estimation of equation (12), using HIGH_LAW as partitioning variable. For both AVAR and AVOL the coefficient of the interaction between MANDATORY and POST is not significant, while the estimated coefficient of the interaction between MANDATORY, HIGH_LAW and POST is in the expected direction but it is significant only in model (4) $(0.1076 ; \mathrm{p}<0.05)$. To better assess the role of the legal enforcement in determining the effect of the IFRS mandatory adoption, we combine the coefficients of the variables of interests and test the significance of the aggregate coefficients (Table 4, panel B). Results show that only IFRS mandatory adopters incorporated in strong legal enforcement countries experience a significant increase in AVAR and AVOL (0.107, p-value $<0.1 ; 0.183$, p-value $<0.01$ respectively). Most importantly, only for firms in strong legal enforcement regimes are the changes in AVAR and AVOL for the mandatory adopters relative to the change for the control sample of voluntary adopters still positive and significant $(0.226, \mathrm{p}$-value $<0.01 ; 0.197, \mathrm{p}$-value $<0.01$ respectively $)$.

Next, we examine the effectiveness of the board of directors monitoring intensity in determining financial reporting quality around IFRS mandatory adoption. We claim that stronger board monitoring is likely to enhance the credibility and integrity of firms' financial reports. As a result, we expect that, despite the country of incorporation, firms which bond themselves under the scrutiny of a more monitoring-oriented board should be associated with an increase in financial reporting quality relative to firms for which the boards are less monitoring oriented. Table 4 (panel A, models (5)-(6)) reports the estimated coefficients and firm-level clustered 
adjusted t-statistics from the estimation of equation (12), using the strength of board monitoring (GOOD_GOV) as partitioning variable. In models (5)-(6), the coefficients of the interaction between MANDATORY and POST are not significant, suggesting that firms for which board of directors are poor monitors do not experience a significant change in financial reporting practices around IFRS mandatory adoption. On the contrary, the estimated coefficients of the interaction between MANDATORY, GOOD_GOV and POST are significant and in the expected directions $(0.0699, \mathrm{p}<0.10 ; 0.1772, \mathrm{p}<0.01$, respectively). Panel B of Table 4 reports the $2 \times 2$ table partitioned in the strong versus weak board monitoring intensity, used to test the significance of the aggregate coefficients. We find a significant increase in both AVAR and AVOL only for strong board monitoring firms $(0.124, \mathrm{p}$-value $<0.01 ; 0.300$, p-value $<0.01$, respectively). For these groups, the change is positive and significant after we take into account the change for the control sample of the voluntary adopters with a similar board monitoring level $(0.258$, p-value $<0.05 ; 0.194$, p-value $<0.01$, respectively). On the contrary, for the weak board-monitoring firms, we do not find a significant change once IFRS became mandated. Overall, our results show that, by itself, IFRS adoption has little effect on firms' reporting behavior. By contrast, we find that board-based monitoring mechanisms have an effective role in shaping firms' reporting quality after a change in accounting standards.

Finally, we examine the interplay between country-level and firm-level board monitoring intensity. So far, we show that strong board-based monitoring mechanisms can substitute for lax legal enforcement. Nevertheless, we cannot derive fully correct inferences about the effectiveness of board monitoring as a substitute of the legal system from prior analyses. First, almost 67 per cent of the strong-monitoring firms come from strong enforcement countries, thus the results from the estimation of models (5)-(6) could be driven only by strongmonitoring firms which also come from these countries. Most importantly, we have to test whether, holding constant the legal environment, strong monitoring firms behave in a different fashion from weak monitoring firms to assess that firm-level monitoring mechanisms substitute for country-level monitoring mechanisms. Still using a difference-in-difference design to disentangle the effect of concurrent events around IFRS adoption, we augment model (11) to include the full interaction between adopter type, POST, GOOD_GOV and HIGH_LAW. In this way we can compare the changes in financial reporting quality among four groups of firms: (1) weak 
monitoring firms in a weak legal enforcement; (2) strong monitoring firms in a weak legal enforcement; (3) weak monitoring firms in a strong legal enforcement; (4) strong monitoring firms in a strong legal enforcement

Table 4, panel A (models 7 and 8) reports the results from the estimation of equation (13), while panel B reports the $2 \times 2$ table used to test the significance of the aggregate coefficients between the four groups. Looking at Panel B, consistent with the substitution effect between firm-level and country-level monitoring mechanisms, we find an increase in the AVAR and AVOL for strong monitoring firms in weak legal enforcement countries (0.212, p-value $<0.05 ; 0.156, \mathrm{p}$-value $<0.01$, respectively). The positive change for strong monitoring firms holds when we take into account the relative change for the voluntary adopters $(0.292, \mathrm{p}$-value $<0.01 ; 0.159$, pvalue $<0.05$, respectively). Most importantly, keeping fixed the type of adopters and the strength of the legal enforcement, i.e. comparing the changes in financial reporting quality for firms that are forced to switch to IFRS in the same weak legal environment between strong versus weak monitoring firms, we find a significant increase in both AVAR and AVOL $(0.234, \mathrm{p}<0.05 ; 0.097, \mathrm{p}<0.05$, respectively). In other words, strong monitoring firms are able to separate themselves from weak monitoring firms in a weak legal environment, and are thus able to enhance reporting quality further once IFRS are mandated. We also document an improvement in financial reporting quality for weak monitoring firms in a strong legal environment for both AVAR and AVOL (0.216, p $<0.05 ; 0.077, \mathrm{p}<0.10$, respectively), even if such improvement is stronger for strong monitoring firms in the same legal environment.

\section{[INSERT TABLE 4 ABOUT HERE]}

So far, we have explored the effect of firm-level monitoring mechanisms around IFRS mandatory adoption on the information content of annual earnings announcements to verify if board monitoring affects the investors' assessment of the reliability of the outcomes of firms' financial reporting process. As noted by DeFond et al. (2007), the information content of annual earnings announcements is an earnings attribute strongly affected by the reliability of accounting information. Since earnings for firms that engage less in earnings management are more reliable, in the sense that such earnings are more likely to depict firms' underling 
performances (DeFond et al. 2007, Bamber et al. 2011), we should observe a decrease in abnormal accruals after IFRS mandatory adoption only for strong board-based monitoring firms, despite the country of incorporation. In addition, to the extent that a firm may substitute accrual based earnings management with real earnings management, we also examine the impact of IFRS mandatory adoption on real based earnings management.

Table 5 (Panel A) presents the results from the estimation of equation (11) using ABS_DA, REAL_1 and REAL_2 as dependent variables, while Panel B reports the $2 \mathrm{X} 2$ tables used to test the significance of the aggregate coefficient contrasts between the groups. Models (1)-(3) report results without distinguishing firms on the basis of legal enforcement or board monitoring intensity. Overall, it appears that the advent of mandatory IFRS (coefficient for MANDATORY*POST) does not affect ABS_DA (-0.0088, P > 0.10) but translates into more real earnings management, as proxied by higher REAL_1 and REAL_2 $(0.0656, \mathrm{p}<0.10 ; 0.0585, \mathrm{p}<$ 0.10, respectively). To investigate the issue further, we now partition sample firms on the basis of legal enforcement (HIGH_LAW). Results are reported in models (4)-(6). It appears that most of the IFRS effect derives from firms subject to stricter legal enforcement, as none of the coefficients for MANDATORY*POST are statistically significant at conventional levels (such coefficient would capture the effect for firms under weak legal enforcement). In contrast, the coefficient for MANDATORY*HIGH_LAW*POST is negative for ABS_DA $(-0.0026, \mathrm{p}<0.10)$ and positive for both REAL_1 and REAL_2 $(0.0435, \mathrm{p}<0.01 ; 0.0550, \mathrm{p}<0.01$, respectively). Hence, there seems to be a trade-off between accrual management (less) and real earnings management (more) in firms under strong legal enforcement following the advent of IFRS. A similar pattern arises when sample firms are partitioned on the basis of board monitoring intensity (GOOD_GOV) (Models (6)(9)). None of the coefficients for MANDATORY*POST are statistically significant at conventional levels (such coefficient would capture the effect for firms under weak board monitoring). In contrast, the coefficient for MANDATORY*GOOD_GOV*POST is negative for ABS_DA $(-0.0079, \mathrm{p}<0.01)$ and positive for both REAL_1 and REAL_2 $(0.0524, \mathrm{p}<0.01 ; 0.0558, \mathrm{p}<0.01$, respectively). Hence, there seems to be a trade-off between accrual management (less) and real earnings management (more) in firms with strong board monitoring following the advent of IFRS. Results reported on Panel B essentially corroborate the above evidence. Overall, results from table 5 show that, by itself, IFRS mandatory adoption has little if no effect on firms' reporting 
behavior. By contrast, we find that both board and legal monitoring mechanisms have an effective role in shaping firms' reporting quality after a change in accounting standards. The next analysis investigates this issue further.

\section{[INSERT TABLE 5 ABOUT HERE]}

Finally, we examine the interplay between country-level enforcement and firm-level monitoring mechanisms around IFRS mandatory adoption also for accrual-based and real earnings management metrics. Table 6 (panel A) presents the results from the estimation of equation (12) using ABS_DA, REAL_1 and REAL_2 as dependent variables, while panel $\mathrm{B}$ reports the $2 \times 2$ tables used to test the significance of the aggregate coefficient contrasts between the groups. To facilitate the interpretation, we move directly to panel B. We find a decrease in ABS_DA for strong monitoring firms in weak legal enforcement countries $(-0.017$, pvalue<0.01), even after taking into account the relative change for the voluntary adopters $(-0.013$, pvalue $<0.001)$. Keeping fixed the type of adopters and the strength of the legal enforcement, i.e. comparing the changes in ABS_DA for firms forced to switch to IFRS in the same legal environment between strong versus weak monitoring firms, we still find a significant decrease in the absolute value of discretionary accruals $(-0.010$, p-value<0.05). We also document a decrease in ABS_DA for mandated adopters with strong monitoring in strong legal enforcement countries $(-0.016, \mathrm{p}<0.01 ;-0.014, \mathrm{p}<0.05$ when relative to voluntary adopters $)$, while the decrease is lower for weak monitoring firms in the same legal environment (difference between strong monitoring and weak monitoring firms: $-0.005, \mathrm{p}<0.10)$.

For the real earnings management metrics, we find an increase in both REAL_1 and REAL_2 for strong board-based monitoring firms, irrespective of the strength of a country legal enforcement. In contrast, for firms with weak board monitoring, only strong enforcement translates into a rise in real earnings management $(0.050$, $\mathrm{p}<0.10 ; 0.047, \mathrm{p}<0.05$, respectively). In general, firms with strong board monitoring raise their level of real earnings management more than firms with weak board monitoring, irrespective of country level governance. To sum up, if firm-level corporate governance is a substitute for the legal system when it is weak, firm and country- 
level monitoring mechanisms turn to be complements as the latter gets stronger. In addition, firm-level monitoring mechanisms seems to matter most when they are scarce, that is in weak legal enforcement countries as long as the improvement in financial reporting quality for strong monitoring firms relative to weak monitoring firms is larger in lax legal environment than in strong.

\section{[INSERT TABLE 6 ABOUT HERE]}

\section{ADDITIONAL ANALYSIS}

\section{Monitoring versus reporting incentives hypothesis}

This paper exploits cross-sectional variance in board-based monitoring intensity to examine heterogeneity in IFRS mandatory adoption consequences on financial reporting quality. We rely on agency theory to partition the sample according to board monitoring intensity, under the assumption that board structured to be effective watchdogs of insiders' behaviors are more likely to provide financial information of higher quality to reduce agency costs. We examine neither why firms should adopt strong monitoring mechanisms, nor whether the decision to adopt such mechanisms is the observable outcome of firm reporting incentives. Indeed, a firm decision to bond itself to the scrutiny of strong board-based monitoring mechanisms may follow from a particular set of reporting incentives. More profitable firms with greater needs for external financing and higher growth opportunities should have strong incentives to provide more reliable financial information to providers of finance. A firm may try to adopt bonding mechanisms, for example corporate governance ones, to credibly commit not to expropriate investors, especially if the comes from a lax legal system. If this argument holds, we should observe an improvement in financial reporting quality after IFRS mandatory adoption for firms with strong reporting incentives, despite the presence of strong board-based monitoring mechanisms. In this case, corporate governance is just an observable outcome, with no additional explanatory power. To explore this issue, we replicate our main analyses by augmenting the models with a reporting incentives partitioning variable. Specifically, we apply a factor analysis to the following variables: SIZE, LEV, ROA, GROWTH. The first factor (out of two which are retained) exhibits the expected loadings and we use it as our "reporting incentives" 
variable. Following Daske et al. (2012), we calculate the reporting incentives variable as a rolling average over the previous three years (i.e., years $t, t-1, t-2$ ). Next, we subtract for each firm the rolling average in year $t-1$ from the rolling average in year $t+3$ relative to the year $t$ of IFRS adoption. Finally, we create a binary variable (REP_INCENTIVES) based on the sample distributions of the changes around IFRS adoption. Firms with above sample median value of "reporting incentives" are classified as strong reporting incentives firms (REP_INCENTIVES equals to one).

Table 7 (panel A) presents the estimation results while panel B reports the $2 \times 2$ tables used to test the significance of the aggregate coefficient contrasts between the four groups. Focusing on panel B results, e find that only strong board-based monitoring firms exhibit an increase in AVAR and AVOL, and a decline in ABS_DA, irrespective of the reporting incentives although the improvement in all three measures is stronger for those firms that hold also strong reporting incentives. Most importantly, we do not find a decline in ABS_DA and an increase in AVAR and AVOL for firms that have strong reporting incentives but do not adopt strong board-based monitoring mechanisms. Together, these results suggest that our proxy for board monitoring intensity it is not just the observable outcome of a given set of reporting incentives. Rather, it has an additional and different role in explaining financial reporting changes around IFRS mandatory adoption.

[INSERT TABLE 7 ABOUT HERE]

\section{ROBUSTENESS}

In this section, we present the results of a battery of robustness tests. All the results of the robustness checks are untabulated but are available from the authors upon request.

1. To the extent that 2005 is the year of the mandatory switch to IFRS, we replicate all the analyses after excluding the transition year. Results are unchanged.

2. United Kingdom firms represent almost 34 percent of the sample. We replicate all the analyses after excluding United Kingdom. Results are consistent with those reported. 
3. We test whether the results are robust to the use of alternative measures of accrual-based and real earnings management. We measure the abnormal working capital accruals as in DeFond and Park (2001) and inferences are unchanged. In addition, we use the abnormal accruals adjusted for firm performances (Kothary et al. 2005), results are qualitative unchanged. We also use alternative proxies for real earnings management following Cohen et al. (2012) who adjust real earnings management models by controlling for firms' performances and the results are consistent with those reported in the paper.

4. We use the earnings response coefficient as an alternative proxy for the earnings informativeness. Inferences are unchanged.

5. The empirical results of this paper rely on the ability of the board monitoring proxy (i.e. GOOD_GOV) to partition the sample into strong board-based monitoring firms and weak board-based monitoring firms. If the approach used to classify observations fails to properly capture the strength of firm-level monitoring mechanisms, reported findings may be misleading. As a result, we replicate all the analyses employing alternative identification schemes:

i. the extent firm level governance may be affected by a given country corporate law and securities legislation. Hence, we first split the sample into four groups according to a country legal origin (i.e. French, Anglo-Saxon, German, Scandinavian). Then, for each of these groups, we take firms in the upper 20 percent of the firm-specific mean of GOVSCORE and set them as strong board-based monitoring firms. Results are unchanged. We replicate all the analyses using GOVSCORE instead of GOOD_GOV and the results are consistent with those reported;

ii. firm-level corporate governance may change over time, but it evolves slowly. Therefore, we do not focus on board monitoring changes but, rather, on board monitoring levels, under the assumption that cross-sectional differences in terms of board monitoring remain constant over time while firm-specific board monitoring intensity may vary. Indeed, less than 6 percent of firms in the sample went from being classified as weak (strong) board-based monitoring firm in the pre mandatory adoption period (i.e. 2004) to being classified as strong (weak) board-based monitoring firms in the post mandatory adoption period (i.e. 2006). However, we replicate all 
the analyses after taking into account the fact that some firms may be misclassified between the pre and post IFRS adoption. Specifically, we do two separate factor analysis for the year 2004 and 2006 with the same variables used to define GOVSCORE. Then, we re-define GOOD_GOV equals to one if a firm is above the sample median in both 2004 and 2006, zero if it is below the median in both the years. In the other cases, firms are excluded from the sample. Results are consistent with those reported in the paper.

\section{CONCLUSION}

This paper revisits the joint effect of country-level legal enforcement and firm-level governance on the quality of financial reporting. Using a large sample of firms adopting IFRS, we find that firms evolving in weak legal enforcement countries enhance their earnings quality by building up their board-level governance monitoring. This suggests that in weak enforcement countries, firm-level board monitoring and country-level legal enforcement are substitute governance mechanisms. In contrast, in countries with strong legal enforcement, firms with weak board monitoring may still see an improvement in earnings quality but it is smaller than for firms with strong board monitoring. This finding suggests that in strong enforcement countries, firm-level board monitoring is actually a complementary governance mechanism to country-level institutions. Overall, our findings suggest that IFRS adoption by itself does not much affect earnings quality and that any such effect is conditional upon firm- and country-level governance.

The study is subject to some limitations. First, it is restricted to European firms. However, such a restriction allows the consideration of a large sample of firms that converged toward a common set of financial reporting standards at a common time. Second, we focus on a selected set of proxies for earnings quality but it encompasses accruals management, real earnings management and earnings informativeness, a comprehensive portfolio. Future research may consider how country- and firm-level governance interact in influencing earnings quality in other contexts.

\section{References}


Armstrong, C., M. Barth, and E. Riedl. 2010. Market reaction to the adoption of IFRS in Europe. The Accounting Review 85(1): 31-61.

Ball, R., S. P. Kothari, and A. Robin. 2000. The effect of international institutional factors of properties of accounting earnings, Journal of Accounting and Economics 29(1), 1-51.

Ball, R., A. Robin, and J.S. Wu. 2003. Incentives versus standards: properties of accounting income in four East Asian countries, Journal of Accounting and Economics, 36(1-3):. 235-270.

Barth, M. E., W. R. Landsman, and M. Lang. 2008. International Accounting Standards and Accounting Quality. Journal of Accounting Research 46(3): 467-498.

Beneish, M., B. Miller, and T. Yohn. 2010. IFRS adoption and cross-border investment in equity and debt markets, Working paper, Indiana University.

Beuselinck, C., P. Joos, and S. Van der Meulen. 2009. Mandatory IFRS reporting and stock price informativeness, Working paper, Tilburg University and University of Missouri at Columbia.

Burgstahler, D., Hail, L. and Leuz, C. 2006. The importance of reporting incentives: earnings management in European private and public firms. The Accounting Review, 81(5): 983-1016.

Bushman, R. Q. Chen, E. Engel; and A. Smith. 2004. Financial Accounting Information, Organizational Complexity and Corporate Governance Systems. Journal of Accounting and Economics 37(1): 167-201.

Byard, D., L. Ying, and Y. Yu. 2011. The effect of mandatory IFRS adoption on financial analysts information environment. Journal of Accounting Research 49(1): 69-96.

Campbell J. 1996. Understanding Risk and Return. Journal of Political Economy 104(2): 298-345.

Chen, K.C.W., Z. Chen, and K.C.J. Wei. 2009. Legal protection of investors, corporate governance, and the cost of equity capital. Journal of Corporate Finance 15: 273-289

Christensen, H.B., L. Hail, C. Leuz. 2012. Mandatory IFRS reporting and change in enforcement. Working paper.

Cohen, D. A., A. Dey, and T. Z. Lys. 2008. Real and Accrual-Based Earnings Management in the Pre -and PostSarbanes-Oxley Periods. The Accounting Review 83(3): 757-787.

Cohen, D., S. Pandit, C. Wasley, and T. Zach. 2012. Measuring real activity management. Working paper

Das, S., K. Kim, and S. Patro. 2011. An analysis of managerial use and market consequences of earnings management and expectation management. The Accounting Review 86(6): 1935-1967.

Daske, H., L. Hail, C. Leuz, and R. Verdi. 2008. Mandatory IFRS reporting around the world: Early evidence on the economic consequences. Journal of Accounting Research 46 (5): 1085-1142.

Daske, H., L. Hail, C. Leuz, and R. Verdi. 2012. Adopting a Label: Heterogeneity in the Economic Consequences of IFRS Adoptions. Working paper.

Dechow P., R. Sloan, and A. Sweeny. 1995. Detecting Earnings Management. The Accounting Review 70(2): 193-225. 
Dechow, P., R. Sloan, and A. Sweeny. 1996. Causes and Consequences of Earnings Manipulation: An Analysis of Firm Subject to Enforcement Actions by the SEC. Contemporary Accounting Research 13 (1): 1-36

Defond, M.L., and Jiambalvo, J. 1994. Debt covenant violation and manipulation of accruals, Journal of Accounting and Economics 17(1):145-176

DeFond, M., and C. Park. 2001. The Reversal of Abnormal Accruals and the Market Valuation of Earnings Surprises. The Accounting Review 76(3) 375-404.

DeFond, M.L., R.H. Hann, and X. Hu. 2005. Does the market value financial expertise on audit committees of board of directors? Journal of Accounting Research 43(2): 153-193

DeFond M., M. Hung, R. Trezevant. 2007. Investor protection and the information content of annual earnings announcement: International evidence. Journal of Accounting and Economics 43(1): 37-67.

DeFond, M., X. Hu, M. Hung, and S. Li. 2011. The impact of mandatory IFRS adoption on foreign mutual fund ownership: the role of comparability, Journal of Accounting and Economics 51(2), 240-258.

Doidge, C., G.A. Karolyi, and R.M. Stulz. 2007. Why do countries matter so much for corporate governance? Journal of Financial Economics 86(1): 1-39

Durnev, A., and H. Kim. 2005. To steal or not to steal: firm attributes, legal environment, and valuation. Journal of Finance 60, 1461-1493.

Ewert, R., and A. Wagenhofer. 2005. Economic effects of tightening accounting standards to restrict earnings management. The Accounting Review 80(4):1101-25.

Faleye, O., R. Hoitash, and U. Hoitash. 2011. The cost of intense monitoring. Journal of Financial Economics 101(1): 160-181.

Fama, E. 1980. Agency problems and the theory of the firm. Journal of Political Economy 88: 288-307.

Fama, E., and M. Jensen. 1983. Separation of ownership and control. Journal of Law and Economics 26(2): 301325.

Gow, I. D., G. Ormazabal, and D.J. Taylor. 2010. Correcting for cross-sectional and time-series dependence in accounting research. The Accounting Review 85(2): 483-512.

Graham, J., R. Harvey, and S. Rajgopal. 2005. The economic implications of corporate financial reporting. Journal of Accounting and Economics 40(1-3): 3-73.

Hail, L., C. Leuz, and P.D. Wysocki. 2010. Global accounting convergence and the potential adoption of IFRS by the U.S. (Part I): conceptual underpinning and economic analysis. Accounting Horizons 24(3): $355-$ 394.

Haw, In-Mu, B. Hu, L-S Hwang, and W. Wu. 2004. Ultimate ownership, income management, and legal and extra-legal institutions. Journal of Accounting Research 42(2): 423-463

Hribar, P., and C. Nichols. 2007. The use of unsigned earnings quality measures in tests of earnings management. Journal of Accounting Research 45(5): 1017-1053. 
Jensen, M., and W. Meckling. 1976. Theory of the firm: Managerial behaviour, agency costs and ownership structure. Journal of Financial Economics 3, 305-360.

Kaufmann D., A. Kraay, and M. Mastruzzi. 2007. Governance matters VI: Aggregate and individual governance indicators 1996-2006. Working paper, the World Bank.

Klein, A. 2002. Audit committee, board of director characteristics, and earnings management. Journal of Accounting and Economics 33: 375-400.

Kothari, S.P., A.J. Leone, and C. E. Wasley. 2005. Performance matched discretionary accrual measures. Journal of Accounting and Economics 39(1): 163-197.

Krishnan, J., Y. Wen, and W. Zhao. Legal expertise on corporate audit committees and financial reporting quality. The Accounting Review 86(6): 2099-2130

La Porta, R., F. Lopez-de-Silanes, A. Shleifer, and R. Vishny, 1997, Legal determinants of external finance, Journal of Finance 52, 1131-1150.

Landsman, W., E. Maydew, and J. Thornock, 2012, The information content of annual earnings announcements and mandatory adoption of IFRS, Journal of Accounting and Economics, 53(1-2): 34-54.

Larcker, D.F., S.A Richardson, and I. Tuna. 2007. Corporate governance, accounting outcomes, and organizational performance. The Accounting Review 82(4): 963-1008.

Li, S. 2010. Does mandatory adoption of international financial reporting standards in the European Union reduce the cost of equity capital? The Accounting Review 85(2): 607-636.

Lombardo, G., and M. Pagano. 2002. Law and equity markets: a simple model. In: McCahery, J., Moerland, P., Raaijmakers, T., Renneboog, L. (Eds.), Corporate Governance Regimes: Convergence and Diversity. Oxford University Press, Oxford, 343-362.

Leuz, C., D. Nanda, and P.D. Wyscoki. 2003. Earnings management and investor protection: an international comparison, Journal of Financial Economics 69: 505-527.

Nebitt, S.L. 1994. Long-term rewards from shareholders activism: a study of the "CallPERS effect". Journal of Applied Corporate Finance 6(1): 75-80

Peasnell, K.V., P.F. Pope, and S. Young. 2005, Board monitoring and earnings management: do outside directors influence abnormal accruals? Journal of Business Finance \& Accounting 32(7): 1311-1346.

Roychowdhury, S. 2006. Earnings management through real activities manipulation. Journal of Accounting and Economics 42 (3): 335-70.

Shleifer, A., and R. Vishny. 1997. A survey of corporate governance. Journal of Finance 52, 737-783.

Soderstrom, N., and K. Sun. 2007. IFRS adoption and accounting quality: a review. European Accounting Review 16, 675-702.

Song, C.J., W.B. Thomas, and H. Yi. 2010. Value relevance of FAS No. 157 fair value hierarchy information and the impact of corporate governance mechanisms. The Accounting Review 85(4): 1375-1410. 
Tan, H., S. Wang, and M. Welker. 2011. Analyst following and forecast accuracy after mandated IFRS adoptions, Journal of Accounting Research 49, 1307-1357

Wyocki, P.D. 2011. New institutional accounting and IFRS. Accounting and Business Research 41(3): 309-328.

Xie, B., W.N. Davidson III, P.J. DaDalt. 2003. Earnings management and corporate governance: the role of the board and the audit committee. Journal of Corporate Finance 9(2): 295-316

Zang, A. 2012. Evidence on the trade-off between real activities manipulations and accrual-based earnings management. The Accounting Review 87(2): 675-703

Zhao, Y., K.H. Chen, Y. Zhang, and M. Davis. 2012. Takeover protection and managerial myopia: Evidence from real earnings management. Journal of Accounting and Public Policy 31(1): 109-135 
APPENDIX A: Variable Definitions

\begin{tabular}{|c|c|}
\hline Variable & "Definition \\
\hline MANDATORY & $\begin{array}{l}\text { Dummy variable equals to one if a firm does not applies IFRS } \\
\text { until } 2005 \text {, zero otherwise. }\end{array}$ \\
\hline VOLUNTARY & $\begin{array}{l}\text { Dummy variable equals to one if a firm applies IFRS before } \\
2003 \text {, zero otherwise. }\end{array}$ \\
\hline AVAR & $\begin{array}{l}\text { Abnormal return variability computed as in Landsman et al. } \\
\text { (2012). }\end{array}$ \\
\hline AVOL & $\begin{array}{l}\text { Abnormal trading volume computed as in Landsman et al. } \\
\text { (2012). }\end{array}$ \\
\hline ABS_DA & $\begin{array}{l}\text { Absolute value of discretionary accruals computed as in } \\
\text { Dechow et al. (1995). }\end{array}$ \\
\hline REAL_1 & $\begin{array}{l}\text { Sum of the abnormal level of production and the abnormal level } \\
\text { of discretionary expenses (time minus one), both computed as in } \\
\text { Roychowdhury (2006). }\end{array}$ \\
\hline REAL_2 & $\begin{array}{l}\text { Sum of Abnormal level of discretionary expenses (time minus } \\
\text { one) and the abnormal level of cash flow (time minus one), both } \\
\text { computed as in Roychowdhury (2006). }\end{array}$ \\
\hline POST & $\begin{array}{l}\text { Dummy variable equals to one if a firm-year observations falls } \\
\text { in or after } 2005 \text {, zero otherwise. }\end{array}$ \\
\hline SIZE & Natural logarithm of total assets at the beginning of the year. \\
\hline ROA & $\begin{array}{l}\text { Net income before extraordinary items divided by the end of the } \\
\text { year total assets. }\end{array}$ \\
\hline GROWTH & Percentage change in sales. \\
\hline LEV & $\begin{array}{l}\text { End of the year total liabilities divided by end of the year } \\
\text { equity book value. }\end{array}$ \\
\hline DISSUE & $\begin{array}{l}\text { Percentage change in total liabilities divided by end of the year } \\
\text { equity book value. }\end{array}$ \\
\hline TURN & Sales divided by end of year total assets. \\
\hline OPER_CYCLE & The operating cycle in days. \\
\hline$\sigma(\mathrm{CFO})$ & $\begin{array}{l}\text { Standard deviation of the operating cash flow, measured over } \\
\text { the previous } 5 \text { year. }\end{array}$ \\
\hline$\sigma(\mathrm{SALES})$ & $\begin{array}{l}\text { Standard deviation of the sales, measured over the previous } 5 \\
\text { year. }\end{array}$ \\
\hline MBE & $\begin{array}{l}\text { Dummy variable equals to one if a firm meet or beat the last } \\
\text { analyst consensus forecast prior to the earnings announcement, } \\
\text { zero otherwise. }\end{array}$ \\
\hline AFE & $\begin{array}{l}\text { Earnings surprise, defined as the difference between the actual } \\
\text { earnings per share and the analyst consensus earnings forecast } \\
\text { before the earnings announcement, scaled the closing price at } \\
\text { the fiscal year end. }\end{array}$ \\
\hline LOSS & $\begin{array}{l}\text { Dummy variable equals to one if the actual earnings per share is } \\
\text { less than zero, zero otherwise. }\end{array}$ \\
\hline FOLLOWING & $\begin{array}{l}\text { The logarithm of the number of analyst that follow a fir during } \\
\text { the year of the earnings announcement. }\end{array}$ \\
\hline DISPERSION & $\begin{array}{l}\text { Standard deviation of analyst earnings forecasts prior to the } \\
\text { earnings announcement, scaled by the closing price as the end } \\
\text { of the year. }\end{array}$ \\
\hline REP_LAG & $\begin{array}{l}\text { Logarithm of the number of days between the firm's fiscal year } \\
\text { end to the earnings announcement. }\end{array}$ \\
\hline
\end{tabular}


APPENDIX B: Governance Attributes Definitions

\begin{tabular}{|c|c|}
\hline Variable & Definition \\
\hline BOARD SIZE & Number of board members. \\
\hline INDEPENDENT & Number of independent directors over number of board members. \\
\hline OUTSIDERS & Number of outsiders directors over number of board members. \\
\hline INSIDERS & Number of insiders directors over number of board members. \\
\hline FINANCIAL EXPERT & $\begin{array}{l}\text { Number of financial expert independent directors over number of board } \\
\text { members. }\end{array}$ \\
\hline ACCOUNTING & $\begin{array}{l}\text { Number of accounting expert independent directors over number of board } \\
\text { members. }\end{array}$ \\
\hline AUDIT & $\begin{array}{l}\text { Dummy equals to } 1 \text { if the board has set up an audit committee, } 0 \\
\text { otherwise. }\end{array}$ \\
\hline AUDIT_SIZE & Number of board members serving on the audit committee. \\
\hline INDEPENDENT_AUDIT & $\begin{array}{l}\text { Number of independent directors serving on the audit committee over } \\
\text { number of board members serving on the audit committee. }\end{array}$ \\
\hline OUTSIDERS_AUDIT & $\begin{array}{l}\text { Number of outsiders directors serving on the audit committee over number } \\
\text { of board members serving on the audit committee. }\end{array}$ \\
\hline INSIDERS_AUDIT & $\begin{array}{l}\text { Number of insiders directors serving on the audit committee over number } \\
\text { of board members serving on the audit committee. }\end{array}$ \\
\hline $\begin{array}{l}\text { FINANCIAL } \\
\text { EXPERT_AUDIT }\end{array}$ & $\begin{array}{l}\text { Number of independent directors financial expert serving on the audit } \\
\text { committee over number of board members serving on the audit committee. }\end{array}$ \\
\hline ACCOUNTING_AUDIT & $\begin{array}{l}\text { Number of independent directors accounting expert serving on the audit } \\
\text { committee over number of board members serving on the audit committee. }\end{array}$ \\
\hline GOVSCORE & $\begin{array}{l}\text { Standardized governance score based on principal component factor } \\
\text { analysis of the six governance attributes. }\end{array}$ \\
\hline GOOD_GOV & $\begin{array}{l}\text { Dummy equals to one if GOVSCORE is higher than the sample median, } \\
\text { zero otherwise. }\end{array}$ \\
\hline
\end{tabular}


Table 1

Distribution of Observations by Country

\begin{tabular}{|c|c|c|c|c|c|}
\hline & \multicolumn{2}{|c|}{$\begin{array}{c}\text { Pre -Mandatory Adotption } \\
\text { Period } \\
(2002-2004) \\
\end{array}$} & \multicolumn{2}{|c|}{$\begin{array}{c}\text { Post - Mandatory Adotption } \\
\text { Period } \\
(2005-2008) \\
\end{array}$} & \multirow[t]{2}{*}{ Rule of Law } \\
\hline & Firms-years & Percent using IFRS & Firms-years & Percent using IFRS & \\
\hline Austria & 3 & 0.66 & 6 & 1 & $1.8(1)$ \\
\hline Belgium & 28 & 0.11 & 35 & 1 & $1.4(0)$ \\
\hline Denmark & 35 & 0.25 & 44 & 1 & $1.9(1)$ \\
\hline Finland & 75 & 0.12 & 102 & 1 & $1.9(1)$ \\
\hline France & 312 & 0.08 & 441 & 1 & $1.3(0)$ \\
\hline Germany & 280 & 0.53 & 383 & 1 & $1.7(1)$ \\
\hline Greece & 12 & 0.00 & 15 & 1 & $0.7(0)$ \\
\hline Italy & 95 & 0.00 & 130 & 1 & $0.5(0)$ \\
\hline Netherlands & 38 & 0.00 & 50 & 1 & $1.7(1)$ \\
\hline Norway & 50 & 0.00 & 79 & 1 & $1.9(1)$ \\
\hline Spain & 39 & 0.00 & 55 & 1 & $1.1(0)$ \\
\hline Sweden & 94 & 0.00 & 130 & 1 & $1.8(1)$ \\
\hline Switzerland & 120 & 0.73 & 155 & 1 & $2.0(1)$ \\
\hline United Kingdom & 678 & 0.01 & 941 & 1 & $1.6(1)$ \\
\hline Total & 1,862 & 0.15 & 2,566 & 1 & \\
\hline
\end{tabular}


Table 2

Descriptive Statistics for Governance Attributes

\begin{tabular}{|c|c|c|c|c|c|c|c|c|}
\hline \multicolumn{9}{|c|}{ Panel A: Descriptive statistics } \\
\hline Variable & $N$ & Mean & Std. Dev & P5 & $\mathrm{P} 25$ & Median & P75 & P95 \\
\hline BOARD SIZE & 4,425 & 9.3719 & 4.6045 & 4 & 6 & 8 & 11 & 18 \\
\hline INDEPENDENT & 4,425 & 0.3536 & 0.2219 & 0.0000 & 0.2000 & 0.3333 & 0.5000 & 0.7500 \\
\hline OUTSIDERS & 4,425 & 0.6677 & 0.1933 & 0.3750 & 0.5000 & 0.6667 & 0.8000 & 1 \\
\hline INSIDERS & 4,425 & 0.3322 & 0.1933 & 0.0000 & 0.2000 & 0.3333 & 0.5000 & 0.6250 \\
\hline FINANCIAL EXPERT & 4,425 & 0.2151 & 0.1804 & 0.0000 & 0.0909 & 0.2000 & 0.3333 & 0.5556 \\
\hline ACCOUNTING & 4,425 & 0.0471 & 0.0793 & 0.0000 & 0.0000 & 0.0000 & 0.0909 & 0.2000 \\
\hline AUDIT & 4,425 & 0.6249 & 0.4841 & 0.0000 & 0.0000 & 1.0000 & 1.0000 & 1.0000 \\
\hline AUDIT_SIZE & 4,425 & 2.1103 & 1.9416 & 0 & 0 & 2 & 3 & 5 \\
\hline INDEPENDENT_AUDIT & 4,425 & 0.3918 & 0.38457 & 0.0000 & 0.0000 & 0.3333 & 0.6666 & 1.0000 \\
\hline OUTSIDERS_AUDIT & 4,425 & 0.6107 & 0.4817 & 1.0000 & 1.0000 & 1.0000 & 1.0000 & 1.0000 \\
\hline INSIDERS_AUDIT & 4,425 & 0.0141 & 0.0910 & 0.0000 & 0.0000 & 0.0000 & 0.0000 & 0.0000 \\
\hline $\begin{array}{l}\text { FINANCIAL } \\
\text { EXPERT_AUDIT }\end{array}$ & 4,425 & 0.2879 & 0.3252 & 0.0000 & 0.0000 & 0.2000 & 0.5000 & 1.0000 \\
\hline $\begin{array}{l}\text { ACCOUNTING } \\
\text { AUDIT }\end{array}$ & 4,425 & 0.0720 & 0.1590 & 0.0000 & 0.0000 & 0.0000 & 0.0000 & 0.5000 \\
\hline INST_OWN & 4,425 & 14.6859 & 16.5367 & 0.0000 & 0.0000 & 8.6400 & 23.5500 & 55.0600 \\
\hline
\end{tabular}

Panel B: Governance factor score and sample adequacy

Variables

Factor Loading Coefficients
Kaiser-Meyer-Olkin Measure of Sampling Adequacy

INDEPENDENT

0.4606

0.6516

0.7316

AUDIT

0.8922

0.7884

0.8553

0.7336

INDEPENDENT_AUDIT

0.9415

0.7886

0.8789

0.9270

0.2558

$57.73 \%$

Mean $\mathrm{KMO}=0.7533$

Variation Explained

3.4639

Eigenvalue

Panel C: Descriptive statistics of governance factor score

\begin{tabular}{lccccccccc} 
Variable & $N$ & Mean & Std. Dev & P5 & P25 & Median & P75 & P95 \\
\hline GOVSCORE & 4,425 & 0.0000 & 1.0000 & -1.2212 & -1.1487 & 0.2147 & 0.8766 & 1.4658 \\
\hline
\end{tabular}

Table 2, panel A reports descriptive statistics for the corporate governance variables. Panel B presents the results of the principal component factor analysis.

See APPENDIX A and B for variable definitions 
Table 3

Descriptive statistics for Variables Used in Regression Analyses

\begin{tabular}{|c|c|c|c|c|c|c|c|c|}
\hline Variable & $N$ & Mean & Std. Dev & P5 & P25 & Median & P75 & P95 \\
\hline AVAR & 4,425 & 0.1720 & 0.8654 & -1.1770 & -0.3359 & 0.1902 & 0.7206 & 1.5443 \\
\hline AVOL & 4,425 & 0.6231 & 0.7181 & 0.7181 & 0.1724 & 0.5112 & 0.9508 & 1.8489 \\
\hline ABS_DA & 4,425 & 0.0569 & 0.0621 & 0.0033 & 0.0176 & 0.0388 & 0.0766 & 0.1631 \\
\hline REAL 1 & 4,425 & -0.0460 & 0.2182 & -0.4126 & -0.1558 & -0.0293 & 0.0729 & 0.2760 \\
\hline REAL 2 & 4,425 & -0.0429 & 0.2171 & -0.3742 & -0.1616 & -0.0300 & 0.0757 & 0.2827 \\
\hline SIZE & 4,425 & 6.5082 & 1.9631 & 3.6425 & 5.0747 & 6.2712 & 7.7752 & 10.155 \\
\hline ROA & 4,425 & 0.0376 & 0.0943 & -0.1327 & 0.0151 & 0.0468 & 0.0828 & 0.1593 \\
\hline GROWTH & 4,425 & 0.1942 & 2.1729 & -0.2313 & 0.0027 & 0.1334 & 0.2488 & 0.5863 \\
\hline LEV & 4,425 & 1.2510 & 35.079 & 0.2702 & 0.7646 & 1.3601 & 2.1808 & 4.6366 \\
\hline DISSUE & 4,425 & 0.1822 & 0.4011 & -0.2406 & -0.0175 & 0.1008 & 0.2680 & 0.8894 \\
\hline TURN & 4,425 & 0.0109 & 0.0067 & 0.0031 & 0.0067 & 0.0097 & 0.0133 & 0.0228 \\
\hline OPER_CYCLE & 4,425 & 136.71 & 94.203 & 43.379 & 85.856 & 120.14 & 156.83 & 279.85 \\
\hline$\sigma(\mathrm{CFO})$ & 4,425 & 150.26 & 446.87 & 2.4203 & 0.7820 & 22.089 & 77.622 & 705.11 \\
\hline$\sigma(\mathrm{SALES})$ & 4,425 & 669.66 & 1833.7 & 7.4509 & 34.204 & 116.69 & 419.98 & 3352.1 \\
\hline MBE & 4,425 & 0.5796 & 0.4936 & 0 & 0 & 1 & 1 & 1 \\
\hline LOSS & 4,425 & 0.1169 & 0.3214 & 0 & 0 & 0 & 1 & 1 \\
\hline FOLLOWING & 4,425 & 3.3411 & 1.0481 & 1.6094 & 2.5649 & 3.4011 & 4.1588 & 4.9698 \\
\hline AFE & 4,425 & 0.0864 & 1.1537 & 0.0004 & 0.0023 & 0.0061 & 0.0173 & 0.1205 \\
\hline DISPERSION & 4,425 & 0.3289 & 7.8063 & 0.0000 & 0.0000 & 0.0004 & 0.0025 & 0.0486 \\
\hline REP_LAG & 4,425 & 4.2066 & 0.3946 & 3.5835 & 3.9702 & 4.2195 & 4.4426 & 4.8441 \\
\hline
\end{tabular}


Table 4: Panel A

$O L S$ regressions on AVAR and AVOL conditional on the strength of the legal enforcement and firm-level board monitoring intensity

\begin{tabular}{|c|c|c|c|c|c|c|c|c|}
\hline & $\begin{array}{c}(1) \\
\text { AVAR } \\
\end{array}$ & $\begin{array}{c}(2) \\
\text { AVOL } \\
\end{array}$ & $\begin{array}{c}(3) \\
\text { AVAR } \\
\end{array}$ & $\begin{array}{c}(4) \\
\text { AVOL } \\
\end{array}$ & $\begin{array}{c}5) \\
\text { AVAR } \\
\end{array}$ & $\begin{array}{c}6) \\
\text { AVOL } \\
\end{array}$ & $\begin{array}{c}(7) \\
\text { AVAR } \\
\end{array}$ & $\begin{array}{c}(8) \\
\text { AVOL } \\
\end{array}$ \\
\hline MANDATORY & $\begin{array}{c}0.8904 * * * \\
(2.794)\end{array}$ & $\begin{array}{c}0.9645 * * * \\
(3.886)\end{array}$ & $\begin{array}{c}0.5802 * * \\
(2.327)\end{array}$ & $\begin{array}{c}1.7419 * * * \\
(9.466)\end{array}$ & $\begin{array}{c}0.6405 * * * \\
(2.666)\end{array}$ & $\begin{array}{c}1.7484 * * * \\
(9.908)\end{array}$ & $\begin{array}{c}0.5941 * * \\
(2.325)\end{array}$ & $\begin{array}{c}1.8195 * * * \\
(9.846)\end{array}$ \\
\hline VOLUNTARY & $\begin{array}{c}0.9901 * * * \\
(3.016)\end{array}$ & $\begin{array}{c}0.9545 * * * \\
(3.842)\end{array}$ & $\begin{array}{c}0.7032 * * \\
(2.432)\end{array}$ & $\begin{array}{c}1.6284 * * * \\
(8.169)\end{array}$ & $\begin{array}{c}0.6478 * * \\
(2.580)\end{array}$ & $\begin{array}{c}1.5958 * * * \\
(8.707)\end{array}$ & $\begin{array}{c}0.8125^{* * *} \\
(2.399)\end{array}$ & $\begin{array}{c}1.6165 * * * \\
(7.508)\end{array}$ \\
\hline MANDATORY*POST & $\begin{array}{l}0.1217 \\
(1.092)\end{array}$ & $\begin{array}{c}0.2465^{* *} * \\
(2.288)\end{array}$ & $\begin{array}{l}0.0637 \\
(0.932)\end{array}$ & $\begin{array}{l}0.0746 \\
(1.566)\end{array}$ & $\begin{array}{l}0.0540 \\
(0.836)\end{array}$ & $\begin{array}{l}0.1231 \\
(1.634)\end{array}$ & $\begin{array}{l}-0.0220 \\
(-0.265)\end{array}$ & $\begin{array}{l}0.0588 \\
(1.100)\end{array}$ \\
\hline VOLUNTARY*POST & $\begin{array}{l}-0.1036 \\
(-0.829)\end{array}$ & $\begin{array}{l}0.0891 \\
(1.167)\end{array}$ & $\begin{array}{l}-0.1210 \\
(-0.823)\end{array}$ & $\begin{array}{l}-0.0038 \\
(-0.049)\end{array}$ & $\begin{array}{l}-0.1111 \\
(-1.254)\end{array}$ & $\begin{array}{l}0.0399 \\
(0.475)\end{array}$ & $\begin{array}{l}-0.1801 \\
(-0.809)\end{array}$ & $\begin{array}{l}-0.0034 \\
(-0.023)\end{array}$ \\
\hline MANDATORY*HIGH_LAW & & & $\begin{array}{l}0.0160 \\
(0.304)\end{array}$ & $\begin{array}{l}0.0136 \\
(0.377)\end{array}$ & & & $\begin{array}{l}0.0093 \\
(0.136)\end{array}$ & $\begin{array}{l}-0.0391 \\
(-0.858)\end{array}$ \\
\hline VOLUNTARY*HIGH_LAW & & & $\begin{array}{l}-0.1006 \\
(-0.622)\end{array}$ & $\begin{array}{l}-0.0539 \\
(-0.622)\end{array}$ & & & $\begin{array}{l}-0.2160 \\
(-0.908)\end{array}$ & $\begin{array}{l}0.0263 \\
(0.209)\end{array}$ \\
\hline MANDATORY*HIGH_LAW*POST & & & $\begin{array}{l}0.0424 \\
(0.673)\end{array}$ & $\begin{array}{c}0.1076 * * \\
(2.422)\end{array}$ & & & $\begin{array}{l}0.1331 \\
(1.491)\end{array}$ & $\begin{array}{l}-0.0075 \\
(-0.129)\end{array}$ \\
\hline VOLUNTARY*HIGH_LAW*POST & & & $\begin{array}{l}0.0021 \\
(0.013)\end{array}$ & $\begin{array}{l}-0.0115 \\
(-0.147)\end{array}$ & & & $\begin{array}{l}0.0746 \\
(0.321)\end{array}$ & $\begin{array}{l}-0.0224 \\
(-0.151)\end{array}$ \\
\hline MANDATORY*GOOD_GOV & & & & & $\begin{array}{l}0.0258 \\
(0.480)\end{array}$ & $\begin{array}{l}0.0302 \\
(0.863)\end{array}$ & $\begin{array}{l}0.0080 \\
(0.089)\end{array}$ & $\begin{array}{c}-0.0882^{*} \\
(-1.816)\end{array}$ \\
\hline VOLUNTARY*GOOD_GOV & & & & & $\begin{array}{l}0.0892 \\
(0.673)\end{array}$ & $\begin{array}{l}-0.0118 \\
(-0.188)\end{array}$ & $\begin{array}{l}-0.1301 \\
(-0.429)\end{array}$ & $\begin{array}{l}0.1181 \\
(0.789)\end{array}$ \\
\hline MANDATORY*GOOD_GOV*POST & & & & & $\begin{array}{c}0.0699 * \\
(1.954)\end{array}$ & $\begin{array}{c}0.1772 * * * \\
(3.939)\end{array}$ & $\begin{array}{c}0.2335^{* *} \\
(2.199)\end{array}$ & $\begin{array}{l}0.0972 * * \\
(2.453)\end{array}$ \\
\hline VOLUNTARY*GOOD_GOV*POST & & & & & $\begin{array}{l}-0.0234 \\
(-0.164)\end{array}$ & $\begin{array}{l}0.0659 \\
(1.008)\end{array}$ & $\begin{array}{l}0.1005 \\
(0.364)\end{array}$ & $\begin{array}{l}-0.0002 \\
(-0.001)\end{array}$ \\
\hline MANDATORY*HIGH_LAW*GOOD_GOV & & & & & & & $\begin{array}{l}0.0181 \\
(0.164)\end{array}$ & $\begin{array}{c}0.1784 * * * \\
(2.811)\end{array}$ \\
\hline VOLUNTARY*.HIGH_LAW*GOOD_GOV & & & & & & & $\begin{array}{l}0.2346 \\
(0.685)\end{array}$ & $\begin{array}{l}-0.1473 \\
(-0.896)\end{array}$ \\
\hline MANDATORY*HIGH_LAW*GOOD_GOV*POST & & & & & & & $\begin{array}{c}-0.2399 * \\
(-1.856)\end{array}$ & $\begin{array}{l}0.1018 \\
(1.108)\end{array}$ \\
\hline VOLUNTARY*HIGH_LAW*GOOD_GOV*POST & & & & & & & $\begin{array}{l}-0.1442 \\
(-0.450)\end{array}$ & $\begin{array}{l}-0.0243 \\
(-0.413)\end{array}$ \\
\hline SIZE & $\begin{array}{l}0.0167 \\
(1.290)\end{array}$ & $\begin{array}{c}-0.0494 * * * \\
(-5.105)\end{array}$ & $\begin{array}{c}0.0228 * \\
(1.802)\end{array}$ & $\begin{array}{c}-0.0528 * * * \\
(-5.454)\end{array}$ & $\begin{array}{l}0.0163 \\
(1.310)\end{array}$ & $\begin{array}{c}-0.0611 * * * \\
(-6.232)\end{array}$ & $\begin{array}{l}0.0177 \\
(1.388)\end{array}$ & $\begin{array}{c}-0.0625 * * * \\
(-6.443)\end{array}$ \\
\hline LEV & $\begin{array}{l}0.0015 \\
(0.292)\end{array}$ & $\begin{array}{l}-0.0000 \\
(-0.023)\end{array}$ & $\begin{array}{l}0.0002 \\
(0.641)\end{array}$ & $\begin{array}{l}-0.0001 \\
(-0.307)\end{array}$ & $\begin{array}{l}0.0002 \\
(0.708)\end{array}$ & $\begin{array}{l}-0.0000 \\
(-0.191)\end{array}$ & $\begin{array}{l}0.0002 \\
(0.827)\end{array}$ & $\begin{array}{l}-0.0000 \\
(-0.206)\end{array}$ \\
\hline LOSS & $\begin{array}{l}-0.0067 \\
(-0.140)\end{array}$ & $\begin{array}{l}-0.0225 \\
(-0.604)\end{array}$ & $\begin{array}{l}-0.0285 \\
(-0.597)\end{array}$ & $\begin{array}{l}-0.0309 \\
(-0.793)\end{array}$ & $\begin{array}{l}-0.0294 \\
(-0.615)\end{array}$ & $\begin{array}{l}-0.0388 \\
(-1.026)\end{array}$ & $\begin{array}{l}-0.0309 \\
(-0.643)\end{array}$ & $\begin{array}{l}-0.0277 \\
(-0.741)\end{array}$ \\
\hline AFE & $\begin{array}{l}-0.0100 \\
(-0.594)\end{array}$ & $\begin{array}{c}-0.0189 * * * \\
(-2.767)\end{array}$ & $\begin{array}{l}-0.0118 \\
(-0.715)\end{array}$ & $\begin{array}{c}-0.0171 * * * \\
(-2.766)\end{array}$ & $\begin{array}{l}-0.0123 \\
(-0.752)\end{array}$ & $\begin{array}{c}-0.0177 * * \\
(-2.450)\end{array}$ & $\begin{array}{l}-0.0125 \\
(-0.755)\end{array}$ & $\begin{array}{c}-0.0191 * * * \\
(-2.916)\end{array}$ \\
\hline DISPERSION & $\begin{array}{l}0.0017 \\
(0.694)\end{array}$ & $\begin{array}{c}0.0038^{* * * *} \\
(5.313)\end{array}$ & $\begin{array}{l}0.0016 \\
(0.702)\end{array}$ & $\begin{array}{c}0.0035^{* * *} \\
(5.663)\end{array}$ & $\begin{array}{l}0.0017 \\
(0.740)\end{array}$ & $\begin{array}{c}0.0038^{* * *} \\
(5.175)\end{array}$ & $\begin{array}{l}0.0019 \\
(0.799)\end{array}$ & $\begin{array}{c}0.0038^{* * * *} \\
(5.970)\end{array}$ \\
\hline REP_LAG & $\begin{array}{c}-0.216 * * * \\
(-4.735)\end{array}$ & $\begin{array}{c}-0.1385^{* * * *} \\
(-4.264)\end{array}$ & $\begin{array}{c}-0.2070 * * * \\
(-4.905)\end{array}$ & $\begin{array}{c}-0.1639 * * * \\
(-5.204)\end{array}$ & $\begin{array}{c}-0.2150 * * * \\
(-5.199)\end{array}$ & $\begin{array}{c}-0.1816 \text { **** } \\
(-5.780)\end{array}$ & $\begin{array}{c}-0.2056 \text { *** } \\
(-4.853)\end{array}$ & $\begin{array}{c}-0.1788 * * * \\
(-5.774)\end{array}$ \\
\hline FOLLOWING & $\begin{array}{l}0.0001 \\
(0.008)\end{array}$ & $\begin{array}{c}-0.0710 * * * \\
(-5.132)\end{array}$ & $\begin{array}{l}-0.0057 \\
(-0.346)\end{array}$ & $\begin{array}{c}-0.0707 * * * \\
(-5.036)\end{array}$ & $\begin{array}{l}-0.0045 \\
(-0.275)\end{array}$ & $\begin{array}{c}-0.0743 \text { *** } \\
(-5.377)\end{array}$ & $\begin{array}{l}-0.0052 \\
(-0.319)\end{array}$ & $\begin{array}{c}-0.0667 * * * * \\
(-4.907)\end{array}$ \\
\hline$\triangle \mathrm{CAP} / \mathrm{GDP}$ & $\begin{array}{c}0.2604 * \\
(1.747)\end{array}$ & $\begin{array}{l}-0.0520 \\
(-0.395) \\
\end{array}$ & $\begin{array}{c}0.0760 * * \\
(2.264)\end{array}$ & $\begin{array}{c}0.1829 * * * \\
(7.018)\end{array}$ & $\begin{array}{c}0.0606^{*} \\
(1.723)\end{array}$ & $\begin{array}{c}0.1648^{* * * *} \\
(6.142)\end{array}$ & $\begin{array}{l}0.0585 \\
(1.602) \\
\end{array}$ & $\begin{array}{c}0.1350 * * * \\
(4.985)\end{array}$ \\
\hline Year fixed effects & Yes & Yes & Yes & Yes & Yes & Yes & Yes & Yes \\
\hline Industry fixed effects & Yes & Yes & Yes & Yes & Yes & Yes & Yes & Yes \\
\hline Country fixed effects & Yes & Yes & No & No & Yes & Yes & No & No \\
\hline Observations & 4,425 & 4,425 & 4,425 & 4,425 & 4,425 & 4,425 & 4,425 & 4,425 \\
\hline R-squared & 0.070 & 0.524 & 0.070 & 0.510 & 0.070 & 0.520 & 0.072 & 0.517 \\
\hline
\end{tabular}


Table 4: Panel B - Two-by-Two analysis on the role of firm-level corporate governance versus country-level legal enforcement in explaining financial reporting quality around IFRS adoption using coefficients in Panel A

\begin{tabular}{|c|c|c|c|c|c|c|c|c|}
\hline \multirow[t]{2}{*}{ AVAR } & \multicolumn{2}{|c|}{ Weak Enforcement } & \multirow[b]{2}{*}{ Diff } & \multicolumn{4}{|c|}{ Strong Enforcement } & \multirow[t]{2}{*}{ Strong - Weak } \\
\hline & PRE & POST & & & PRE & POST & Diff & \\
\hline MANDATORY & 0.580 & 0.644 & 0.064 & MANDATORY & 0.596 & 0.703 & $0.107^{*}$ & 0.042 \\
\hline VOLUNTARY & 0.703 & 0.582 & -0.121 & VOLUNTARY & 0.603 & 0.484 & -0.119 & \\
\hline Diff & -0.123 & 0.062 & 0.185 & Diff & -0.007 & $0.219 * * *$ & $0.226 * * *$ & \\
\hline \multirow[t]{2}{*}{ AVOL } & \multicolumn{2}{|c|}{ Weak Enforcement } & & & \multicolumn{2}{|c|}{ Strong Enforcement } & & \\
\hline & PRE & POST & Diff & & PRE & POST & Diff & \\
\hline MANDATORY & 0.580 & 0.655 & 0.075 & MANDATORY & 0.596 & 0.779 & $0.183 * * *$ & $0.108 * *$ \\
\hline VOLUNTARY & 0.703 & 0.699 & -0.004 & VOLUNTARY & 0.603 & 0.587 & -0.015 & \\
\hline Diff & -0.123 & -0.045 & 0.078 & Diff & $-0.006^{* *}$ & $0.191 * *$ & $0.197 * * *$ & \\
\hline \multirow[t]{2}{*}{ AVAR } & \multicolumn{2}{|c|}{ Weak Governance } & & & \multicolumn{2}{|c|}{ Strong Governance } & & Strong - Weak \\
\hline & PRE & POST & Diff & & PRE & POST & Diff & \\
\hline MANDATORY & 0.640 & 0.694 & 0.054 & MANDATORY & 0.666 & 0.791 & $0.124 * *$ & $0.069 *$ \\
\hline VOLUNTARY & 0.648 & 0.536 & -0.111 & VOLUNTARY & 0.737 & 0.603 & -0.134 & \\
\hline Diff & -0.007 & 0.157 & 0.165 & Diff & -0.071 & $0.187 * *$ & $0.258 * *$ & \\
\hline \multirow[t]{2}{*}{ AVOL } & \multicolumn{2}{|c|}{ Weak Governance } & & & \multicolumn{2}{|c|}{ Strong Governance } & & \\
\hline & PRE & POST & Diff & & PRE & POST & Diff & \\
\hline MANDATORY & 1.748 & 1.872 & 0.123 & MANDATORY & 1.779 & 2.078 & $0.300 * * *$ & $0.177 * * *$ \\
\hline VOLUNTARY & 1.595 & 1.635 & 0.039 & VOLUNTARY & 1.584 & 1.689 & 0.106 & \\
\hline Diff & $0.153 * * *$ & $0.235 * * *$ & 0.083 & Diff & $0.194 * * *$ & $0.389 * * *$ & $0.194 * * *$ & \\
\hline AVAR & \multicolumn{2}{|c|}{$\begin{array}{l}\text { Weak Enforcement } \\
\text { Weak Governance }\end{array}$} & & & \multicolumn{2}{|c|}{$\begin{array}{l}\text { Weak Enforcement } \\
\text { Strong Governance }\end{array}$} & & Strong - Weak \\
\hline MANDATORY & 0.594 & 0.572 & -0.022 & MANDATORY & 0.602 & 0.814 & $0.212 * *$ & $0.234 * *$ \\
\hline VOLUNTARY & 0.812 & 0.632 & -0.180 & VOLUNTARY & 0.682 & 0.603 & -0.080 & \\
\hline \multirow[t]{2}{*}{ Diff } & -0.218 & -0.060 & 0.158 & Diff & -0.080 & 0.211 & $0.292 * *$ & \\
\hline & \multicolumn{2}{|c|}{$\begin{array}{l}\text { Strong Enforcement } \\
\text { Weak Governance }\end{array}$} & & & \multicolumn{2}{|c|}{$\begin{array}{l}\text { Strong Enforcement } \\
\text { Strong Governance }\end{array}$} & & \\
\hline MANDATORY & 0.603 & 0.714 & $0.111^{*}$ & MANDATORY & 0.629 & 0.734 & $0.104 * *$ & -0.007 \\
\hline VOLUNTARY & 0.596 & 0.490 & -0.105 & VOLUNTARY & 0.701 & 0.551 & -0.149 & \\
\hline Diff & 0.007 & $0.223^{*}$ & $0.216^{* *}$ & Diff & -0.072 & 0.182 & $0.254 * *$ & \\
\hline AVOL & \multicolumn{2}{|c|}{$\begin{array}{l}\text { Weak Enforcement } \\
\text { Weak Governance }\end{array}$} & & & \multicolumn{2}{|c|}{$\begin{array}{l}\text { Weak Enforcement } \\
\text { Strong Governance }\end{array}$} & & \\
\hline MANDATORY & 1.819 & 1.878 & 0.059 & MANDATORY & 1.731 & 1.887 & $0.156^{* *}$ & $0.097 * *$ \\
\hline VOLUNTARY & 1.616 & 1.613 & -0.003 & VOLUNTARY & 1.735 & 1.730 & -0.005 & \\
\hline \multirow[t]{2}{*}{ Diff } & $0.203^{*}$ & $0.265^{*}$ & 0.062 & Diff & -0.003 & $0.156^{*}$ & $0.159 * *$ & \\
\hline & \multicolumn{2}{|c|}{$\begin{array}{l}\text { Strong Enforcement } \\
\text { Weak Governance }\end{array}$} & & & \multicolumn{2}{|c|}{$\begin{array}{l}\text { Strong Enforcement } \\
\text { Strong Governance }\end{array}$} & & \\
\hline MANDATORY & 1.780 & 1.831 & 0.051 & MANDATORY & 1.871 & 2.021 & $0.151 * * *$ & $0.100 *$ \\
\hline VOLUNTARY & 1.643 & 1.617 & -0.026 & VOLUNTARY & 1.614 & 1.663 & 0.049 & \\
\hline Diff & $0.138 * *$ & $0.215 * *$ & $0.077 *$ & Diff & $0.257 * * *$ & $0.357 * * *$ & $0.101 * * *$ & \\
\hline
\end{tabular}


Table 5: Panel A

OLS regressions on accrual-based and real earnings management

\begin{tabular}{|c|c|c|c|c|c|c|c|c|c|}
\hline & $\begin{array}{c}(1) \\
\text { ABS_DA } \\
\end{array}$ & $\begin{array}{c}(2) \\
\text { REAL_1 } \\
\end{array}$ & $\begin{array}{c}(3) \\
\text { REAL_2 } \\
\end{array}$ & $\begin{array}{c}(4) \\
\text { ABS_DA }\end{array}$ & $\begin{array}{c}(5) \\
\text { REAL_1 } \\
\end{array}$ & $\begin{array}{c}(6) \\
\text { REAL_2 } \\
\end{array}$ & $\begin{array}{c}(7) \\
\text { ABS_DA }\end{array}$ & $\begin{array}{c}(8) \\
\text { REAL_1 } \\
\end{array}$ & $\begin{array}{c}(9) \\
\text { REAL_2 }\end{array}$ \\
\hline MANDATORY & $\begin{array}{c}0.1113 * * * \\
(4.685)\end{array}$ & $\begin{array}{c}-0.3264 * \\
(-1.840)\end{array}$ & $\begin{array}{l}-0.2692 \\
(-1.606)\end{array}$ & $\begin{array}{c}0.0932 * * * \\
(5.163)\end{array}$ & $\begin{array}{c}-0.2150 \text { *** } \\
(-4.311)\end{array}$ & $\begin{array}{c}-0.1875 * * * \\
(-3.317)\end{array}$ & $\begin{array}{c}0.1151 * * * \\
(14.612)\end{array}$ & $\begin{array}{l}-0.2562 \\
(-1.477)\end{array}$ & $\begin{array}{c}-0.1920 * * * \\
(-6.157)\end{array}$ \\
\hline VOLUNTARY & $\begin{array}{c}0.1155^{* * * *} \\
(4.689)\end{array}$ & $\begin{array}{l}-0.2853 \\
(-1.605)\end{array}$ & $\begin{array}{l}-0.2204 \\
(-1.312)\end{array}$ & $\begin{array}{c}0.0965 * * * \\
(5.205)\end{array}$ & $\begin{array}{c}-0.2757 * * * \\
(-8.478)\end{array}$ & $\begin{array}{c}-0.2536 * * * \\
(-6.079)\end{array}$ & $\begin{array}{c}0.1132 * * * \\
(16.368)\end{array}$ & $\begin{array}{l}-0.1982 \\
(-1.139)\end{array}$ & $\begin{array}{c}-0.1591 * * * \\
(-3.524)\end{array}$ \\
\hline MANDATORY*POST & $\begin{array}{l}-0.0088 \\
(-1.291)\end{array}$ & $\begin{array}{c}0.0656^{*} \\
(2.083)\end{array}$ & $\begin{array}{c}0.0585^{*} \\
(1.984)\end{array}$ & $\begin{array}{l}-0.0113 \\
(-1.516)\end{array}$ & $\begin{array}{l}0.0378 \\
(1.547)\end{array}$ & $\begin{array}{l}0.0207 \\
(0.744)\end{array}$ & $\begin{array}{l}-0.0072 \\
(-1.726)\end{array}$ & $\begin{array}{l}0.0366 \\
(1.056)\end{array}$ & $\begin{array}{l}0.0093 \\
(0.500)\end{array}$ \\
\hline VOLUNTARY*POST & $\begin{array}{l}-0.0125 \\
(-1.563)\end{array}$ & $\begin{array}{l}0.0325 \\
(1.008)\end{array}$ & $\begin{array}{l}0.0218 \\
(0.660)\end{array}$ & $\begin{array}{l}-0.0067 \\
(-0.720)\end{array}$ & $\begin{array}{l}0.0263 \\
(0.848)\end{array}$ & $\begin{array}{l}0.0460 \\
(1.609)\end{array}$ & $\begin{array}{l}-0.0029 \\
(-0.684)\end{array}$ & $\begin{array}{l}0.0204 \\
(0.592)\end{array}$ & $\begin{array}{l}-0.0029 \\
(-0.401)\end{array}$ \\
\hline MANDATORY*HIGH_LAW & - & - & - & $\begin{array}{c}0.0161 * * * \\
(2.927)\end{array}$ & $\begin{array}{c}-0.0577 * * \\
(-2.173)\end{array}$ & $\begin{array}{l}-0.0504 \\
(-1.746)\end{array}$ & - & - & - \\
\hline VOLUNTARY*HIGH_LAW & - & - & - & $\begin{array}{l}0.0062 \\
(0.836)\end{array}$ & $\begin{array}{l}0.0476 \\
(1.432)\end{array}$ & $\begin{array}{c}0.0689 * * \\
(2.867)\end{array}$ & - & - & - \\
\hline MANDATORY*HIGH_LAW*POST & - & - & - & $\begin{array}{c}-0.0026^{*} \\
(-1.646)\end{array}$ & $\begin{array}{c}0.0435 * * * \\
(3.412)\end{array}$ & $\begin{array}{c}0.0550 * * * \\
(3.698)\end{array}$ & - & - & - \\
\hline VOLUNTARY*HIGH_LAW*POST & - & - & - & $\begin{array}{l}0.0028 \\
(0.351)\end{array}$ & $\begin{array}{l}0.0026 \\
(0.135)\end{array}$ & $\begin{array}{l}-0.0283 \\
(-1.519)\end{array}$ & - & - & - \\
\hline MANDATORY *GOOD_GOV & - & - & - & - & - & - & $\begin{array}{c}0.0045^{*} \\
(2.000)\end{array}$ & $\begin{array}{c}-0.0477 * * * \\
(-2.665)\end{array}$ & $\begin{array}{c}-0.0524 * \\
(-2.113)\end{array}$ \\
\hline VOLUNTARY *GOOD_GOV & - & - & - & - & - & - & $\begin{array}{l}0.0003 \\
(0.070)\end{array}$ & $\begin{array}{c}-0.1019 * * * \\
(-3.465)\end{array}$ & $\begin{array}{c}-0.0893^{*} \\
(-2.139)\end{array}$ \\
\hline MANDATORY $*$ GOOD_GOV* POST & - & - & - & - & - & - & $\begin{array}{c}-0.0079 * * * \\
(-2.954)\end{array}$ & $\begin{array}{c}0.0524 * * * \\
(3.240)\end{array}$ & $\begin{array}{c}0.0558^{* * * *} \\
(3.635)\end{array}$ \\
\hline VOLUNTARY*GOOD_GOV* POST & - & - & - & - & - & - & $\begin{array}{l}0.0008 \\
(0.128)\end{array}$ & $\begin{array}{l}0.0174 \\
(0.613)\end{array}$ & $\begin{array}{l}0.0068 \\
(0.149)\end{array}$ \\
\hline ROA & $\begin{array}{c}-0.0008 * * * \\
(-4.548)\end{array}$ & $\begin{array}{c}-0.0035^{* * * *} \\
(-5.636)\end{array}$ & $\begin{array}{c}-0.0036 * * * \\
(-5.996)\end{array}$ & $\begin{array}{c}-0.0006 * * * \\
(-3.879)\end{array}$ & $\begin{array}{c}-0.0025 * * * \\
(-3.756)\end{array}$ & $\begin{array}{c}-0.0034 * * * \\
(-6.643)\end{array}$ & $\begin{array}{c}-0.0006^{* * * *} \\
(-6.644)\end{array}$ & $\begin{array}{c}-0.0025 * * * \\
(-4.579)\end{array}$ & $\begin{array}{c}-0.0024 * * * \\
(-5.657)\end{array}$ \\
\hline SIZE & $\begin{array}{c}-0.0077 * * * \\
(-6.341)\end{array}$ & $\begin{array}{c}0.0169 * * * \\
(3.586)\end{array}$ & $\begin{array}{c}0.0161 * * * \\
(3.547)\end{array}$ & $\begin{array}{c}-0.0075 * * * \\
(-6.720)\end{array}$ & $\begin{array}{c}0.0169 * * * \\
(3.645)\end{array}$ & $\begin{array}{c}0.0151^{* * *} \\
(3.122)\end{array}$ & $\begin{array}{c}-0.0072 * * * \\
(-8.785)\end{array}$ & $\begin{array}{c}0.0194 * * * \\
(3.993)\end{array}$ & $\begin{array}{c}0.0175 * * * \\
(3.658)\end{array}$ \\
\hline GROWTH & $\begin{array}{l}0.0000 \\
(0.259)\end{array}$ & $\begin{array}{l}-0.0000 \\
(-0.896)\end{array}$ & $\begin{array}{l}-0.0000 \\
(-0.430)\end{array}$ & $\begin{array}{l}0.0000 \\
(0.649)\end{array}$ & $\begin{array}{l}-0.0000 \\
(-0.879)\end{array}$ & $\begin{array}{l}-0.0000 \\
(-1.039)\end{array}$ & $\begin{array}{l}0.0000 \\
(0.775)\end{array}$ & $\begin{array}{l}-0.0000 \\
(-0.818)\end{array}$ & $\begin{array}{l}-0.0000 \\
(-0.982)\end{array}$ \\
\hline LEV & $\begin{array}{l}-0.0000 \\
(-0.703)\end{array}$ & $\begin{array}{l}-0.0000 \\
(-0.386)\end{array}$ & $\begin{array}{l}-0.0001 \\
(-0.977)\end{array}$ & $\begin{array}{l}-0.0000 \\
(-0.708)\end{array}$ & $\begin{array}{l}-0.0000 \\
(-0.293)\end{array}$ & $\begin{array}{l}-0.0001 \\
(-0.797)\end{array}$ & $\begin{array}{l}-0.0000 \\
(-0.770)\end{array}$ & $\begin{array}{l}-0.0000 \\
(-0.153)\end{array}$ & $\begin{array}{l}-0.0001 \\
(-0.673)\end{array}$ \\
\hline DISSUE & $\begin{array}{c}0.0001 * * * \\
(3.151)\end{array}$ & $\begin{array}{l}0.0001 \\
(1.298)\end{array}$ & $\begin{array}{c}0.0004 * * * \\
(4.112)\end{array}$ & $\begin{array}{c}0.0001 * * * \\
(2.720)\end{array}$ & $\begin{array}{l}0.0000 \\
(1.262)\end{array}$ & $\begin{array}{c}0.0001 * \\
(1.859)\end{array}$ & $\begin{array}{c}0.0001 * * \\
(2.753)\end{array}$ & $\begin{array}{l}0.0001 \\
(0.777)\end{array}$ & $\begin{array}{l}0.0001^{*} \\
(1.945)\end{array}$ \\
\hline OPER_CYCLE & $\begin{array}{c}0.0001 * * * \\
(3.193)\end{array}$ & $\begin{array}{c}0.0003 * * * \\
(4.738)\end{array}$ & $\begin{array}{c}0.0003 * * * \\
(4.580)\end{array}$ & $\begin{array}{c}0.0000 * * * \\
(2.971)\end{array}$ & $\begin{array}{c}0.0002 * * \\
(2.383)\end{array}$ & $\begin{array}{c}0.0002 * * * \\
(3.414)\end{array}$ & $\begin{array}{c}0.0000 * * * \\
(4.733)\end{array}$ & $\begin{array}{c}0.0002 * * * \\
(3.128)\end{array}$ & $\begin{array}{c}0.0002 * * * \\
(3.840)\end{array}$ \\
\hline TURN & $\begin{array}{c}0.0077 * * * \\
(2.618)\end{array}$ & $\begin{array}{c}0.1530 * * * \\
(8.028)\end{array}$ & $\begin{array}{c}0.1570 * * * \\
(8.946)\end{array}$ & $\begin{array}{c}0.0052 * * \\
(2.321)\end{array}$ & $\begin{array}{c}0.1441 * * * \\
(10.347)\end{array}$ & $\begin{array}{c}0.1470 * * * \\
(11.958)\end{array}$ & $\begin{array}{c}0.0041^{* *} \\
(2.637)\end{array}$ & $\begin{array}{c}0.1421 * * * \\
(7.583)\end{array}$ & $\begin{array}{c}0.1332 * * * \\
(14.126)\end{array}$ \\
\hline MBE & $\begin{array}{c}-0.0096 * * * \\
(-4.688)\end{array}$ & $\begin{array}{c}-0.0273 * * * \\
(-4.137)\end{array}$ & $\begin{array}{c}-0.0259 * * * \\
(-3.926)\end{array}$ & $\begin{array}{c}-0.0061 * * * \\
(-3.325)\end{array}$ & $\begin{array}{c}-0.0289 * * * \\
(-7.973)\end{array}$ & $\begin{array}{c}-0.0260 * * * \\
(-6.365)\end{array}$ & $\begin{array}{c}-0.0068 * * * \\
(-3.103)\end{array}$ & $\begin{array}{c}-0.0292 * * * \\
(-4.386)\end{array}$ & $\begin{array}{c}-0.0241 * * * \\
(-5.515)\end{array}$ \\
\hline$\sigma($ REVENUES) & $\begin{array}{l}-0.0000 \\
(-0.888)\end{array}$ & $\begin{array}{l}0.0000 \\
(1.595)\end{array}$ & $\begin{array}{l}0.0000 \\
(1.245)\end{array}$ & $\begin{array}{l}-0.0000 \\
(-0.267)\end{array}$ & $\begin{array}{l}0.0000 \\
(0.581)\end{array}$ & $\begin{array}{l}0.0000 \\
(0.512)\end{array}$ & $\begin{array}{l}-0.0000 \\
(-0.234)\end{array}$ & $\begin{array}{l}0.0000 \\
(1.464)\end{array}$ & $\begin{array}{l}0.0000 \\
(0.521)\end{array}$ \\
\hline$\sigma\left(\mathrm{FCFO} \_U S D\right)$ & $\begin{array}{c}0.0000 * * * \\
(3.022)\end{array}$ & $\begin{array}{c}-0.0001 * * * \\
(-4.602)\end{array}$ & $\begin{array}{c}-0.0001 * * * \\
(-4.173)\end{array}$ & $\begin{array}{c}0.0000^{* * * *} \\
(4.165)\end{array}$ & $\begin{array}{c}-0.0001^{*} \\
(-1.920)\end{array}$ & $\begin{array}{c}-0.0001^{*} \\
(-2.071)\end{array}$ & $\begin{array}{c}0.0000 * * * \\
(8.235)\end{array}$ & $\begin{array}{c}-0.0001 * * * \\
(-4.565)\end{array}$ & $\begin{array}{c}-0.0001 * \\
(-2.027)\end{array}$ \\
\hline$\Delta \mathrm{CAP} / \mathrm{GDP}$ & $\begin{array}{l}0.0024 \\
(0.204) \\
\end{array}$ & $\begin{array}{l}-0.0027 \\
(-0.081)\end{array}$ & $\begin{array}{l}-0.0286 \\
(-0.886) \\
\end{array}$ & $\begin{array}{c}-0.0079 * * * \\
(-2.732)\end{array}$ & $\begin{array}{c}0.0473 * * \\
(2.566)\end{array}$ & $\begin{array}{c}0.0346^{*} \\
(2.026)\end{array}$ & $\begin{array}{l}-0.0037 \\
(-0.568) \\
\end{array}$ & $\begin{array}{l}0.0481 \\
(1.341)\end{array}$ & $\begin{array}{c}0.0387 * * * \\
(3.337)\end{array}$ \\
\hline Year & Yes & Yes & Yes & Yes & Yes & Yes & Yes & Yes & Yes \\
\hline Industry fixed effects & Yes & Yes & Yes & Yes & Yes & Yes & Yes & Yes & Yes \\
\hline Country fixed effects & Yes & Yes & Yes & No & No & No & Yes & Yes & Yes \\
\hline Observations & 4,425 & 4,425 & 4,425 & 4,425 & 4,425 & 4,425 & 4,425 & 4,425 & 4,425 \\
\hline R-squared & 0.510 & 0.219 & 0.216 & 0.534 & 0.201 & 0.201 & 0.536 & 0.217 & 0.212 \\
\hline
\end{tabular}

See APPENDIX A and B for variable definitions. In parentheses are reported t-statics based on robust standard errors that are clustered at firm level.

$* * *, * *$ and $*$ denote significance at $1 \%, 5 \%$ and $10 \%$ levels (two-tailed), respectively 
Table 5: Panel B - Two-by-Two analysis on the role of firm-level corporate governance versus country-level legal enforcement in explaining financial reporting quality around IFRS adoption using coefficients in Panel A

\begin{tabular}{|c|c|c|c|c|c|c|c|c|}
\hline \multirow[t]{2}{*}{ ABS_DA } & \multicolumn{2}{|c|}{ Weak Enforcement } & \multirow[b]{2}{*}{ Diff } & & \multicolumn{2}{|c|}{ Strong Enforcement } & \multirow[b]{2}{*}{ Diff } & \multirow[t]{2}{*}{ Strong - Weak } \\
\hline & PRE & POST & & & PRE & POST & & \\
\hline MANDATORY & 0.093 & 0.082 & -0.011 & MANDATORY & 0.109 & 0.095 & $-0.014 * *$ & $-0.003 *$ \\
\hline VOLUNTARY & 0.096 & 0.089 & -0.007 & VOLUNTARY & 0.102 & 0.098 & -0.004 & \\
\hline Diff & -0.003 & -0.008 & -0.005 & Diff & 0.006 & -0.004 & $-0.010 * *$ & \\
\hline \multirow[t]{2}{*}{ REAL 1} & \multicolumn{2}{|c|}{ Weak Enforcement } & \multicolumn{5}{|c|}{ Strong Enforcement } & \\
\hline & PRE & POST & Diff & & PRE & POST & Diff & \\
\hline MANDATORY & -0.215 & -0.177 & 0.038 & MANDATORY & -0.272 & -0.191 & $0.081 * * *$ & $0.043 * * *$ \\
\hline VOLUNTARY & -0.275 & -0.249 & 0.026 & VOLUNTARY & -0.228 & -0.200 & 0.028 & \\
\hline Diff & 0.061 & 0.072 & 0.012 & Diff & -0.044 & 0.008 & $0.052 * * *$ & \\
\hline \multirow[t]{2}{*}{ REAL 2} & \multicolumn{2}{|c|}{ Weak Enforcement } & \multicolumn{5}{|c|}{ Strong Enforcement } & \\
\hline & PRE & POST & Diff & & PRE & POST & Diff & \\
\hline MANDATORY & -0.187 & -0.166 & 0.021 & MANDATORY & -0.238 & -0.162 & $0.076 * * *$ & $0.055^{* * *}$ \\
\hline VOLUNTARY & -0.253 & -0.207 & 0.046 & VOLUNTARY & -0.185 & -0.167 & 0.0176 & \\
\hline Diff & $0.066^{*}$ & $0.042 *$ & $-0.025^{*}$ & Diff & $-0.053^{*}$ & 0.005 & $0.058 * * *$ & \\
\hline \multirow[t]{2}{*}{ ABS_DA } & \multicolumn{2}{|c|}{ Weak Governance } & & & \multicolumn{2}{|c|}{ Strong Governance } & & Strong - Weak \\
\hline & PRE & POST & Diff & & PRE & POST & Diff & \\
\hline MANDATORY & 0.115 & 0.108 & -0.007 & MANDATORY & 0.119 & 0.104 & $-0.015 * * *$ & $-0.008 * * *$ \\
\hline VOLUNTARY & 0.113 & 0.110 & -0.003 & VOLUNTARY & 0.113 & 0.111 & -0.002 & \\
\hline Diff & 0.002 & -0.002 & -0.004 & Diff & 0.006 & -0.007 & $-0.013 * *$ & \\
\hline \multirow[t]{2}{*}{ REAL 1} & \multicolumn{2}{|c|}{ Weak Governance } & \multicolumn{5}{|c|}{ Strong Governance } & \\
\hline & PRE & POST & Diff & & PRE & POST & Diff & \\
\hline MANDATORY & -0.256 & -0.220 & 0.036 & MANDATORY & -0.304 & -0.215 & $0.089 * * *$ & $0.052 * * *$ \\
\hline VOLUNTARY & -0.198 & -0.178 & 0.020 & VOLUNTARY & -0.300 & -0.262 & 0.038 & \\
\hline Diff & $-0.057^{*}$ & -0.042 & 0.016 & Diff & -0.004 & 0.045 & $0.051 * *$ & \\
\hline \multirow[t]{2}{*}{ REAL 2} & \multicolumn{2}{|c|}{ Weak Governance } & \multicolumn{5}{|c|}{ Strong Governance } & \\
\hline & PRE & POST & Diff & & PRE & POST & Diff & \\
\hline MANDATORY & -0.192 & -0.183 & 0.009 & MANDATORY & -0.244 & -0.179 & $0.065 * * *$ & $0.056 * * *$ \\
\hline VOLUNTARY & -0.159 & -0.162 & -0.003 & VOLUNTARY & -0.248 & -0.244 & 0.004 & \\
\hline Diff & -0.033 & -0.021 & 0.012 & Diff & 0.004 & $0.065^{* *}$ & $0.061 *$ & \\
\hline
\end{tabular}


Table 6: Panel A

OLS regressions on accrual-based and real earnings management conditional on the strength of the legal enforcement and firm-level board monitoring intensity

\begin{tabular}{|c|c|c|c|}
\hline & $\begin{array}{c}(1) \\
\text { ABS_DA } \\
\end{array}$ & $\begin{array}{c}(2) \\
\text { REAL_1 } \\
\end{array}$ & $\begin{array}{c}(3) \\
\text { REAL_2 } \\
\end{array}$ \\
\hline MANDATORY & $\begin{array}{c}0.0940 * * * \\
(8.593)\end{array}$ & $\begin{array}{c}-0.2362 * * * \\
(-4.432)\end{array}$ & $\begin{array}{c}-0.2098 * * * \\
(-3.587)\end{array}$ \\
\hline VOLUNTARY & $\begin{array}{c}0.0994 * * * \\
(7.043)\end{array}$ & $\begin{array}{c}-0.2503 * * * \\
(-5.480)\end{array}$ & $\begin{array}{c}-0.2079 * * * \\
(-3.765)\end{array}$ \\
\hline MANDATORY*POST & $\begin{array}{l}-0.0074 \\
(-1.656)\end{array}$ & $\begin{array}{l}0.0218 \\
(1.127)\end{array}$ & $\begin{array}{l}-0.0034 \\
(-0.157)\end{array}$ \\
\hline VOLUNTARY*POST & $\begin{array}{c}-0.0089 * \\
(-1.865)\end{array}$ & $\begin{array}{c}0.0902 * * * \\
(5.152)\end{array}$ & $\begin{array}{c}0.0992 * * * \\
(4.590)\end{array}$ \\
\hline MANDATORY*HIGH_LAW & $\begin{array}{c}0.0120 * * \\
(2.220)\end{array}$ & $\begin{array}{c}-0.0738 * * \\
(-2.436)\end{array}$ & $\begin{array}{c}-0.0682 * * \\
(-2.247)\end{array}$ \\
\hline VOLUNTARY*HIGH_LAW & $\begin{array}{c}0.0061 * \\
(1.985)\end{array}$ & $\begin{array}{l}-0.0049 \\
(-0.138)\end{array}$ & $\begin{array}{l}-0.0045 \\
(-0.158)\end{array}$ \\
\hline MANDATORY*HIGH_LAW*POST & $\begin{array}{l}-0.0017 \\
(-0.475)\end{array}$ & $\begin{array}{l}0.0287 \\
(1.589)\end{array}$ & $\begin{array}{c}0.0500^{* * * *} \\
(3.507)\end{array}$ \\
\hline VOLUNTARY*HIGH_LAW*POST & $\begin{array}{c}0.0056^{*} \\
(2.082)\end{array}$ & $\begin{array}{c}-0.0720 * * * \\
(-9.361)\end{array}$ & $\begin{array}{c}-0.0908 \text { *** } \\
(-8.737)\end{array}$ \\
\hline MANDATORY*GOOD_GOV & $\begin{array}{c}0.0059^{* *} \\
(2.470)\end{array}$ & $\begin{array}{c}-0.0979 * * \\
(-2.998)\end{array}$ & $\begin{array}{c}-0.1034 * * * \\
(-3.326)\end{array}$ \\
\hline VOLUNTARY*GOOD_GOV & $\begin{array}{l}-0.0015 \\
(-0.321)\end{array}$ & $\begin{array}{c}-0.1056 \text { *** } \\
(-4.135)\end{array}$ & $\begin{array}{c}-0.1144 * * * \\
(-6.156)\end{array}$ \\
\hline MANDATORY*GOOD_GOV*POST & $\begin{array}{c}-0.0101 * * \\
(-2.829)\end{array}$ & $\begin{array}{c}0.0559^{*} \\
(1.924)\end{array}$ & $\begin{array}{c}0.0790 * * \\
(2.844)\end{array}$ \\
\hline VOLUNTARY*GOOD_GOV*POST & $\begin{array}{c}0.0039^{*} \\
(2.041)\end{array}$ & $\begin{array}{c}-0.0806 * * * \\
(-3.979)\end{array}$ & $\begin{array}{c}-0.0850 \text { *** } \\
(-8.062)\end{array}$ \\
\hline MANDATORY*HIGH_LAW*GOOD_GOV & $\begin{array}{l}0.0039 \\
(1.311)\end{array}$ & $\begin{array}{c}0.0773 * * \\
(2.416)\end{array}$ & $\begin{array}{c}0.0844 * * \\
(2.800)\end{array}$ \\
\hline VOLUNTARY*HIGH_LAW*GOOD_GOV & $\begin{array}{l}-0.0016 \\
(-0.196)\end{array}$ & $\begin{array}{l}0.0205 \\
(0.558)\end{array}$ & $\begin{array}{l}0.0256 \\
(0.449)\end{array}$ \\
\hline MANDATORY*HIGH_LAW*GOOD_GOV*POST & $\begin{array}{l}0.0026 \\
(0.546)\end{array}$ & $\begin{array}{l}-0.0142 \\
(-0.435)\end{array}$ & $\begin{array}{l}-0.0413 \\
(-1.371)\end{array}$ \\
\hline VOLUNTARY*HIGH_LAW*GOOD_GOV*POST & $\begin{array}{l}-0.0029 \\
(-0.347)\end{array}$ & $\begin{array}{c}0.1089 * * * \\
(4.198)\end{array}$ & $\begin{array}{l}0.0986 \\
(1.691)\end{array}$ \\
\hline ROA & $\begin{array}{c}-0.0006 * * * \\
(-7.035)\end{array}$ & $\begin{array}{c}-0.0025 * * * \\
(-4.061)\end{array}$ & $\begin{array}{c}-0.0025 * * * \\
(-5.914)\end{array}$ \\
\hline SIZE & $\begin{array}{c}-0.0074 * * * \\
(-7.883)\end{array}$ & $\begin{array}{c}0.0166 * * * \\
(3.789)\end{array}$ & $\begin{array}{c}0.0151 * * \\
(2.624)\end{array}$ \\
\hline GROWTH & $\begin{array}{l}0.0000 \\
(0.624)\end{array}$ & $\begin{array}{l}-0.0000 \\
(-0.904)\end{array}$ & $\begin{array}{l}-0.0000 \\
(-1.014)\end{array}$ \\
\hline LEV & $\begin{array}{l}-0.0000 \\
(-0.790)\end{array}$ & $\begin{array}{l}0.0000 \\
(0.068)\end{array}$ & $\begin{array}{l}-0.0000 \\
(-0.462)\end{array}$ \\
\hline DISSUE & $\begin{array}{c}0.0001 * * \\
(2.944)\end{array}$ & $\begin{array}{l}0.0000 \\
(1.340)\end{array}$ & $\begin{array}{c}0.0001 * \\
(1.893)\end{array}$ \\
\hline OPER_CYCLE & $\begin{array}{c}0.0000^{* *} \\
(2.531)\end{array}$ & $\begin{array}{c}0.0002 * * \\
(2.311)\end{array}$ & $\begin{array}{c}0.0002 * * * \\
(3.287)\end{array}$ \\
\hline TURN & $\begin{array}{c}0.0043 * * * \\
(3.101)\end{array}$ & $\begin{array}{c}0.1461 * * * \\
(9.465)\end{array}$ & $\begin{array}{c}0.1477 * * * * \\
(10.831)\end{array}$ \\
\hline MBE & $\begin{array}{c}-0.0064 * * \\
(-2.899)\end{array}$ & $\begin{array}{c}-0.0291 \text { *** } \\
(-7.030)\end{array}$ & $\begin{array}{c}-0.0274 * * * \\
(-5.738)\end{array}$ \\
\hline$\sigma($ REVENUES) & $\begin{array}{l}-0.0000 \\
(-0.328)\end{array}$ & $\begin{array}{c}-0.0000^{*} \\
(-1.957)\end{array}$ & $\begin{array}{l}-0.0000 \\
(-1.443)\end{array}$ \\
\hline$\sigma(\mathrm{FCFO})$ & $\begin{array}{c}0.0000 * * * \\
(7.872)\end{array}$ & $\begin{array}{c}0.0000 * * * \\
(4.254)\end{array}$ & $\begin{array}{c}0.0000 * * * \\
(3.760)\end{array}$ \\
\hline$\Delta \mathrm{CAP} / \mathrm{GDP}$ & $\begin{array}{c}-0.0092 * * \\
(-2.634)\end{array}$ & $\begin{array}{c}0.0543 * * * \\
(3.937)\end{array}$ & $\begin{array}{c}0.0407 * * * \\
(3.144)\end{array}$ \\
\hline
\end{tabular}

(continued) 


\begin{tabular}{|c|c|c|c|}
\hline Industry fixed effects & Yes & Yes & Yes \\
\hline Country fixed effects & No & No & No \\
\hline Year fixed effects & Yes & Yes & Yes \\
\hline Observations & 4,425 & 4,425 & 4,425 \\
\hline R-squared & 0.533 & 0.201 & 0.200 \\
\hline
\end{tabular}

See APPENDIX A and B for variable definitions. In parentheses are reported t-statics based on robust standard errors that are clustered at firm level. $* * *, * *$ and $*$ denote significance at $1 \%, 5 \%$ and $10 \%$ levels (two-tailed), respectively

Table 6: Panel B - Two-by-Two analysis on the role of firm-level corporate governance versus country-level legal enforcement in explaining financial reporting quality around IFRS adoption using coefficients in Panel A

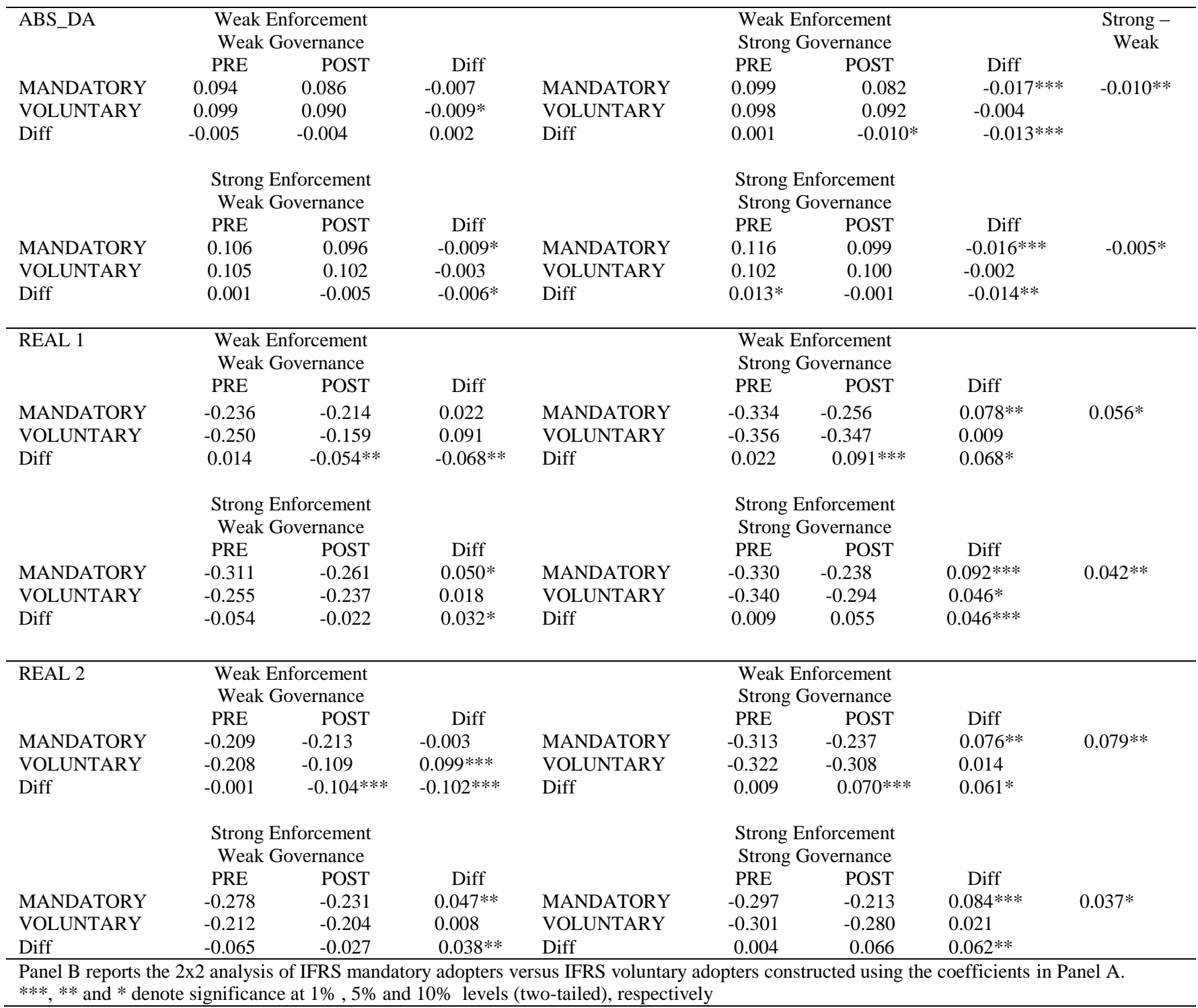


Table 7: Panel A

Monitoring versus reporting incentives




Table 7: Panel B - Two-by-Two analysis on the role of firm-level corporate governance versus reporting incentives in explaining financial reporting quality around IFRS adoption using coefficients in Panel A

\begin{tabular}{|c|c|c|c|c|c|c|c|c|}
\hline \multirow[t]{2}{*}{ AVAR } & \multicolumn{2}{|c|}{$\begin{array}{c}\text { Low reporting incentives } \\
\text { Weak Governance }\end{array}$} & \multirow[b]{2}{*}{ Diff } & \multicolumn{4}{|c|}{$\begin{array}{l}\text { Low reporting incentives } \\
\text { Strong Governance }\end{array}$} & \multirow[t]{2}{*}{$\begin{array}{l}\text { Strong - } \\
\text { Weak }\end{array}$} \\
\hline & PRE & POST & & & PRE & POST & Diff & \\
\hline MANDATORY & 0.922 & 1.044 & 0.122 & MANDATORY & 0.923 & 1.017 & $0.092 * * *$ & -0.0291 \\
\hline VOLUNTARY & 1.015 & 0.846 & $-0.169 *$ & VOLUNTARY & 1.060 & 1.008 & 0.053 & \\
\hline \multirow[t]{4}{*}{ Diff } & $-0.093 *$ & $0.198 * *$ & $0.291 * *$ & Diff & -0.136 & 0.009 & $0.145^{*}$ & \\
\hline & \multicolumn{2}{|c|}{$\begin{array}{l}\text { High reporting } \\
\text { incentives }\end{array}$} & \multicolumn{6}{|c|}{$\begin{array}{l}\text { High reporting } \\
\text { incentives }\end{array}$} \\
\hline & \multicolumn{2}{|c|}{ Weak Governance } & \multicolumn{6}{|c|}{ Strong Governance } \\
\hline & PRE & POST & Diff & & PRE & POST & Diff & \\
\hline MANDATORY & 0.973 & 0.984 & 0.012 & MANDATORY & 0.911 & 1.056 & $0.145^{* * *}$ & $0.132 *$ \\
\hline VOLUNTARY & 0.963 & 0.918 & -0.045 & VOLUNTARY & 1.120 & 0.901 & $-0.219 * *$ & \\
\hline Diff & 0.009 & 0.066 & 0.057 & Diff & -0.209 & 0.154 & $0.364 * * *$ & \\
\hline \multirow[t]{3}{*}{ AVOL } & \multirow{2}{*}{\multicolumn{2}{|c|}{$\begin{array}{l}\text { Low reporting incentives } \\
\text { Weak Governance }\end{array}$}} & \multicolumn{6}{|c|}{ Low reporting incentives } \\
\hline & & & & & Stron & ernance & & \\
\hline & PRE & POST & Diff & & PRE & POST & Diff & \\
\hline MANDATORY & 1.107 & 1.197 & 0.089 & MANDATORY & 1.000 & 1.265 & $0.264 * * *$ & $0.175^{* * * *}$ \\
\hline VOLUNTARY & 1.074 & 1.038 & -0.035 & VOLUNTARY & 1.066 & 1.136 & 0.070 & \\
\hline \multirow[t]{4}{*}{ Diff } & 0.033 & $0.158 *$ & 0.124 & Diff & -0.065 & $0.129 *$ & $0.194 * *$ & \\
\hline & \multicolumn{2}{|c|}{$\begin{array}{l}\text { High reporting } \\
\text { incentives }\end{array}$} & \multicolumn{6}{|c|}{$\begin{array}{l}\text { High reporting } \\
\text { incentives }\end{array}$} \\
\hline & \multicolumn{2}{|c|}{ Weak Governance } & \multicolumn{6}{|c|}{ Strong Governance } \\
\hline & PRE & POST & Diff & & PRE & POST & Diff & \\
\hline MANDATORY & 1.061 & 1.181 & $0.120^{*}$ & MANDATORY & 1.070 & 1.293 & $0.223 * * *$ & $0.103 * *$ \\
\hline VOLUNTARY & 1.003 & 1.062 & 0.059 & VOLUNTARY & 1.010 & 1.067 & 0.056 & \\
\hline Diff & 0.058 & $0.119 *$ & 0.060 & Diff & 0.059 & 0.226 & $0.167 * *$ & \\
\hline \multirow[t]{3}{*}{ ABS_DA } & \multirow{2}{*}{\multicolumn{2}{|c|}{$\begin{array}{c}\text { Low reporting incentives } \\
\text { Weak Governance }\end{array}$}} & \multicolumn{6}{|c|}{ Low reporting incentives } \\
\hline & & & & & Stron & ernance & & \\
\hline & PRE & POST & Diff & & PRE & POST & Diff & \\
\hline MANDATORY & 0.125 & 0.112 & -0.012 & MANDATORY & 0.124 & 0.109 & $-0.015 * *$ & -0.003 \\
\hline VOLUNTARY & 0.114 & 0.112 & -0.001 & VOLUNTARY & 0.115 & 0.113 & -0.002 & \\
\hline Diff & 0.011 & 0.000 & -0.011 & Diff & 0.009 & -0.004 & $-0.013 *$ & \\
\hline & $\begin{array}{r}\mathrm{High} \\
\text { in }\end{array}$ & $\begin{array}{l}\text { orting } \\
\text { ives }\end{array}$ & & & $\begin{array}{r}\mathrm{Hig} \\
\text { il }\end{array}$ & $\begin{array}{l}\text { riting } \\
\text { ves }\end{array}$ & & \\
\hline & Weak & ernance & & & Stron: & ernance & & \\
\hline & PRE & POST & Diff & & PRE & POST & Diff & \\
\hline MANDATORY & 0.114 & 0.110 & -0.004 & MANDATORY & 0.123 & 0.107 & $-0.016^{* *}$ & $-0.012 * *$ \\
\hline VOLUNTARY & 0.121 & 0.113 & -0.008 & VOLUNTARY & 0.113 & 0.115 & $0.002 * *$ & \\
\hline Diff & -0.006 & -0.002 & 0.004 & Diff & 0.010 & -0.007 & -0.018 & \\
\hline REAL_1 & Low repo & incentives & & & Low rep & incentive & & \\
\hline & Weak & ernance & & & Stron & ernance & & \\
\hline & PRE & POST & Diff & & PRE & POST & Diff & \\
\hline MANDATORY & -0.222 & -0.181 & 0.040 & MANDATORY & -0.279 & -0.187 & $0.091 * * *$ & $0.050 * *$ \\
\hline VOLUNTARY & -0.228 & -0.210 & 0.018 & VOLUNTARY & -0.306 & -0.252 & 0.053 & \\
\hline Diff & 0.006 & 0.029 & 0.022 & Diff & 0.027 & $0.065^{*}$ & $0.038 *$ & \\
\hline & $\begin{array}{r}\mathrm{High} \\
\text { in }\end{array}$ & $\begin{array}{l}\text { orting } \\
\text { ives }\end{array}$ & & & $\begin{array}{r}\mathrm{Hig} \\
\text { ir }\end{array}$ & $\begin{array}{l}\text { riting } \\
\text { ves }\end{array}$ & & \\
\hline & Weak & ernance & & & Strong & ernance & & \\
\hline & PRE & POST & Diff & & PRE & POST & Diff & \\
\hline MANDATORY & -0.259 & -0.223 & 0.035 & MANDATORY & -0.315 & -0.229 & $0.086 * *$ & 0.051 \\
\hline VOLUNTARY & -0.146 & -0.115 & 0.031 & VOLUNTARY & -0.224 & -0.204 & 0.018 & \\
\hline Diff & -0.112 & -0.108 & 0.004 & Diff & -0.092 & -0.025 & 0.066 & \\
\hline
\end{tabular}




\begin{tabular}{|c|c|c|c|c|c|c|c|c|}
\hline \multirow{3}{*}{ REAL_2 } & \multirow{2}{*}{\multicolumn{2}{|c|}{$\begin{array}{c}\text { Low reporting incentives } \\
\text { Weak Governance }\end{array}$}} & \multirow{2}{*}{\multicolumn{6}{|c|}{$\begin{array}{l}\text { Low reporting incentives } \\
\text { Strong Governance }\end{array}$}} \\
\hline & & & & & & & & \\
\hline & PRE & POST & Diff & & PRE & POST & Diff & \\
\hline MANDATORY & -0.158 & -0.121 & 0.036 & MANDATORY & -0.211 & -0.125 & $0.086 * * *$ & $0.05^{* *}$ \\
\hline VOLUNTARY & -0.154 & -0.126 & 0.027 & VOLUNTARY & -0.260 & -0.206 & 0.053 & \\
\hline \multirow[t]{3}{*}{ Diff } & -0.004 & 0.005 & 0.009 & Diff & 0.048 & 0.081 & 0.033 & \\
\hline & \multicolumn{2}{|c|}{$\begin{array}{l}\text { High reporting } \\
\text { incentives }\end{array}$} & \multicolumn{6}{|c|}{$\begin{array}{l}\text { High reporting } \\
\text { incentives }\end{array}$} \\
\hline & PRE & POST & Diff & & PRE & POST & Diff & \\
\hline MANDATORY & -0.183 & -0.163 & 0.020 & MANDATORY & -0.235 & -0.157 & $0.078 * *$ & $0.068 * *$ \\
\hline VOLUNTARY & -0.066 & -0.062 & 0.004 & VOLUNTARY & -0.170 & -0.180 & -0.009 & \\
\hline Diff & -0.117 & -0.100 & 0.016 & Diff & -0.065 & 0.028 & 0.087 & \\
\hline
\end{tabular}

